\title{
Do stream water solute concentrations reflect when connectivity occurs in a small, pre-Alpine headwater catchment?
}

\author{
Leonie Kiewiet $^{1}$, Ilja van Meerveld ${ }^{1}$, Manfred Stähli ${ }^{2}$, and Jan Seibert ${ }^{1,3}$ \\ ${ }^{1}$ Department of Geography, University of Zurich, Zurich, Switzerland \\ ${ }^{2}$ Swiss Federal Research Institute WSL, Birmensdorf, Switzerland \\ ${ }^{3}$ Department of Aquatic Sciences and Assessment, Swedish University of Agricultural Sciences, Uppsala, Sweden
}

Correspondence: Leonie Kiewiet (leonie.kiewiet@geo.uzh.ch)

Received: 28 December 2019 - Discussion started: 14 January 2020

Revised: 7 May 2020 - Accepted: 29 May 2020 - Published: 2 July 2020

\begin{abstract}
Expansion of the hydrologically connected area during rainfall events causes previously disconnected areas to contribute to streamflow. If these newly contributing areas have a different hydrochemical composition compared to the previously connected contributing areas, this may cause a change in stream water chemistry that cannot be explained by simple mixing of rainfall and baseflow. Changes in stormflow composition are, therefore, sometimes used to identify when transiently connected areas (or water sources) contribute to stormflow. We identified the dominant sources of streamflow for a steep 20 ha pre-Alpine headwater catchment in Switzerland and investigated the temporal changes in connectivity for four rainfall events based on stream water concentrations and groundwater level data. First, we compared the isotopic and chemical composition of stormflow at the catchment outlet to the composition of rainfall, groundwater and soil water. Three-component end-member mixing analyses indicated that groundwater dominated stormflow during all events, and that soil water fractions were minimal for three of the four events. However, the large variability in soil and groundwater composition compared to the temporal changes in stormflow composition inhibited the determination of the contributions from the different groundwater sources. Second, we estimated the concentrations of different solutes in stormflow based on the mixing fractions derived from twocomponent hydrograph separation using a conservative tracer $\left(\delta^{2} \mathrm{H}\right)$ and the measured concentrations of the solutes in baseflow and rainfall. The estimated concentrations differed from the measured stormflow concentrations for many solutes and samples. The deviations increased gradually with increasing streamflow for some solutes (e.g. iron and copper), sug-
\end{abstract}

gesting increased contributions from riparian and hillslope groundwater with higher concentrations of these solutes and thus increased hydrological connectivity. The findings of this study show that solute concentrations partly reflect the gradual changes in hydrologic connectivity, and that it is important to quantify the variability in the composition of different source areas.

\section{Introduction}

During dry periods only a small part of a catchment is connected to the stream, but the connected area can expand dramatically during rainfall or snowmelt events (Stieglitz et al., 2003; Bracken and Croke, 2007; Jencso and McGlynn, 2011; van Meerveld et al., 2015). Knowledge of which areas are connected and contribute to streamflow is important because it helps us to shape our conceptual understanding of how catchments function. For example, Ladouche et al. (2001) showed for the $0.8 \mathrm{~km}^{2}$ Strengbach catchment in France that the upper layers of saturated areas contributed up to $30 \%$ of the discharge during the initial stages of a rainfall event, even though these areas occupied only $2 \%$ of the catchment area. However, during the final stage of the event, upslope and downslope areas contributed equally to flow. Similarly, Oswald et al. (2011), showed for a $0.8 \mathrm{~km}^{2}$ catchment in northwestern Ontario, Canada, that a large part of the catchment area was hydrologically disconnected from the stream during most events, and that there was a threshold catchment storage at which a larger area contributed to streamflow. Connection of upslope areas does not only lead to large changes in 
discharge (Lehmann et al., 2007; Detty and McGuire, 2010; van Meerveld et al., 2015) but can also cause major changes in stream water composition (e.g. Devito and Hill, 1997; Stieglitz et al., 2003; Ocampo et al., 2006). Interpretations of hydrologic connectivity are often based on such changes in stream water chemistry (Uhlenbrook et al., 2004; Soulsby et al., 2007; Pacific et al., 2010).

Hydrologic connectivity, i.e. "the linkage of separate regions of a catchment via water flow" (Blume and van Meerveld, 2015), is usually inferred from either streambased or hillslope-based measurements because direct observations of connectivity are limited due to the difficulty in observing and quantifying subsurface processes (Hopp and McDonnell, 2009; Blume and van Meerveld, 2015). In many studies, conservative tracers (e.g. stable water isotopes or non-reactive elements) are selected to identify the origin of streamflow, using methods such as hydrograph separation (Buttle, 1994) or end-member mixing analyses (EMMA; Hooper et al., 1990; Christophersen and Hooper, 1992). Tracers can also be used to assess connectivity of hillslopes to the streams (Tetzlaff et al., 2014; Uhlenbrook et al., 2004). Since stream chemistry is the proportional mixture of all actively contributing areas, quantifying each contribution results in a measure for catchment-wide connectivity. For instance, McGlynn and McDonnell (2003) used silica concentrations and isotope data for a 2.6 ha sub-catchment of the Maimai catchment in New Zealand to show that the contributions from the hillslopes were larger for an event with higher wetness conditions than for an event with drier initial conditions and were also larger on the falling limb of the hydrograph. Several studies in the $31 \mathrm{~km}^{2}$ Girnock Burn catchment in Scotland investigated the connectivity of source areas to the stream using Gran alkalinity and isotope data (e.g. Soulsby et al., 2007; Tetzlaff et al., 2014). They found that the upper soil layers and upslope areas increasingly dominated streamflow at higher flows, and that the riparian peat soils modulated the stream water isotopic composition. However, few studies have compared the results from streambased and hillslope-based inferences of connectivity. Burns et al. (1998) showed that hillslope contributions to streamflow inferred from end-member mixing analyses were similar to the subsurface flow measurements for a trenched hillslope.

Mixing analyses are traditionally performed with conservative solutes and stable water isotopes (Hooper and Shoemaker, 1986). Non-conservative solute concentrations can also provide useful information on hydrological connectivity and flow pathways because they can aid the identification of different source areas (Barthold et al., 2011; Abbott et al., 2018). The concentrations of specific elements can also be indicative for differences in redox conditions (e.g. sulfate, iron and manganese), bedrock-contact time (e.g. calcium, magnesium, sodium and barium), or vegetation (e.g. nitrogen, phosphorus and potassium; Kaushal et al., 2018). It has been suggested that the discrepancy between hydrograph separation results for conservative and non-conservative tracers highlights when and where stream water is not the result of conservative mixing between end members, such as baseflow and precipitation (Kirchner, 2003). Instead, it might reflect mixing from different "old" water sources in the catchment that have different concentrations. Therefore, this discrepancy may provide information on when hillslope-stream connectivity is established. Alternatively, the differences in the relative response of conservative and non-conservative tracers during rainfall events might be (partly) due to reactive processes that mobilise (or immobilise) solutes at the event timescale (Godsey et al., 2009). As such, focusing on solute responses in stormflow and the difference between conservative and non-conservative tracers might allow us to identify the extent of these reactive transport processes and contributions from "old" water sources that do not contribute to baseflow.

Solute concentrations in stream water might be relatively constant (chemostatic), decrease (dilution) or increase (mobilisation) in response to rainfall, depending on the source areas to streamflow and their respective concentrations, as well as reactive transport processes (Godsey et al., 2009; Seibert et al., 2009; Knapp et al., 2020). Godsey et al. (2009) found that concentrations of typical weathering products (calcium, magnesium, silica and sodium) were nearly chemostatic for 59 geochemically diverse US catchments, suggesting a (constant) source of these solutes. This implies that the areas that contribute to streamflow during rainfall events have similar concentrations of these solutes as the permanently contributing areas, higher concentrations to compensate for the dilution caused by the rainfall, or that reactions are fast enough to maintain similar concentrations during the event.

The timing of the onset of contributions from different source areas also affects the solute concentrations (Abbott et al., 2018). Several studies have shown that the relationship between concentrations and discharge is hysteretic at the event timescale (e.g. Evans and Davies, 1998; Hornberger et al., 2001). Zuecco et al. (2019) showed that the increase in subsurface connectivity was delayed compared to streamflow (anticlockwise hysteresis) for two sub-catchments of the Studibach catchment in Switzerland, suggesting that hillslope runoff may not be the dominant runoff source at the beginning of rainfall events for these small catchments. If hillslope and riparian zone water have a different composition, this can cause hysteresis in the relationship between solute concentrations and streamflow. Changes in solute concentrations might also depend on the size of the catchment (Brown et al., 1999) and mixing that occurs during transport from the source areas to the outlet. For instance, hillslope runoff may bypass the riparian zone through focused locations along the stream channel or via preferential flow pathways (Allaire et al., 2015) and mix with other hillslope sources (Seibert et al., 2009) and riparian groundwater (McGlynn and McDonnell, 2003; Chanat and Hornberger, 2003) on its way to the stream. 
For all analyses of source areas and connectivity, it is important to quantify the variability in the concentrations of conservative and non-conservative tracers because it affects the robustness of the results and thus interpretations of connectivity. However, for most small $\left(<10 \mathrm{~km}^{2}\right)$ catchment studies it remains unclear how large the changes in stream water composition are compared to the spatial variability in groundwater and soil water because the spatial variability in groundwater and soil water is rarely assessed (Penna and van Meerveld, 2019). In this study, we combined spatially distributed soil- and groundwater sampling with event-based stream water sampling in the pre-Alpine Studibach catchment to address the following research questions:

1. How variable is stream water chemistry during events compared to the spatial variability in soil and groundwater chemistry?

2. What are the dominant sources of streamflow during small to intermediately sized rainfall events?

3. How much do the changes in the concentrations of conservative and non-conservative tracers differ during events, and does this difference provide information on the relative contributions of different parts of the catchment and, thus, hydrological connectivity?

\section{Study catchment}

We conducted this study in the $0.2 \mathrm{~km}^{2}$ pre-Alpine Studibach catchment, a headwater catchment of the Zwäckentobel, located in the Alptal, canton Schwyz, Switzerland. The elevation of the Studibach ranges from 1270 to $1650 \mathrm{~m}$ above sea level. The mean annual precipitation is about $2300 \mathrm{~mm} \mathrm{yr}^{-1}$. The precipitation is relatively evenly distributed throughout the year (Feyen et al., 1999), and about one-third falls as snow (Stähli and Gustafsson, 2006). The catchment is steep (average slope: $35^{\circ}$ ) and characterised by a step-wise topography, with flatter areas and steep slopes due to soil creep and landslides. An open coniferous forest covers about half of the catchment (Hagedorn et al., 2000), a third is characterised as a moor landscape or wet grassland, and the remaining areas are alpine meadows.

Streamflow and groundwater levels respond quickly to rainfall (Fischer et al., 2015; Rinderer et al., 2015). The groundwater level response time is generally less than $30 \mathrm{~min}$ (Rinderer et al., 2014), and only $3 \mathrm{~mm}$ of cumulative rainfall already causes an increase in the groundwater level for a large part of the catchment during typical conditions (Rinderer et al., 2015). The groundwater level peak precedes the peak discharge in the Studibach at half of the sites but only by 15 or $20 \mathrm{~min}$ (Rinderer et al., 2015). Water levels in flatter locations and topographic depressions rise nearly instantaneously, which suggests that they can contribute to streamflow during the early stages of a rainfall event. Previous studies suggest that event water fractions in stormflow are generally low (Kiewiet et al., 2020; von Freyberg et al., 2018), except for events with more than $50 \mathrm{~mm}$ of rainfall (Fischer et al., 2017).

Soils are generally shallow $(0.5 \mathrm{~m}$ at ridge sites to $\sim 2.5 \mathrm{~m}$ in depressions); soil depth is weakly correlated to slope (van Meerveld et al., 2018). The gleysols are underlain by three different types of Flysch bedrock, which is a reworked carbonate rock consisting of deep-water deposits. The carbonate-rich bedrock results in high groundwater concentrations with a calcium-bicarbonate signature, although some sites have high sulfate and magnesium concentrations (Kiewiet et al., 2019).

The Studibach can be subdivided into four different landscape elements with a distinct groundwater composition (Kiewiet et al., 2019 and Fig. 1):

1. Riparian zone, flatter areas and topographic hollows with above-average concentrations of iron and manganese. These areas are from here on referred to as "riparian".

2. Hillslopes and steeper areas, characterised by aboveaverage concentrations of copper, zinc and lead.

3. Areas with above-average concentrations of weathering-derived solutes such as strontium, indicative of longer (and deeper) flow pathways, which are from here on referred to as deep groundwater.

4. Areas located in a specific part of the catchment that is characterised by high magnesium and sulfate concentrations.

\section{Methods}

\subsection{Hydrometric measurements}

To monitor stream water and groundwater levels, we used a network of 51 shallow groundwater wells and streamflow gauges (Fig. 1) that was installed in 2009-2010 (Rinderer et al., 2014). The wells were distributed based on the topographic wetness index (TWI; Beven and Kirkby, 1979) and cover the range of wet and dry locations in the catchment. All wells were drilled by hand to the bedrock ( 0.5 to $2.5 \mathrm{~m}$ depth), screened over the entire length, except for the top $10 \mathrm{~cm}$, and sealed with a layer of bentonite clay. Stream stage was measured directly in the stream (outlet; Fig. 1a) or behind a V-notch weir (C5). Water levels were measured at each well and stream location with either a capacitance water level logger (Odyssey Dataflow Systems Limited) or a pressure transducer (DCX-22 CTD Keller AG für Druckmesstechnick or STS DL/N 70, Sensor Technik Sirnach AG). The pressure data were corrected for changes in barometric pressure and temperature using the data from the MeteoSwiss station in Einsiedeln (910 m a.s.l; ca. $10 \mathrm{~km}$ from the catchment outlet). Rainfall was recorded at three locations within the catchment 


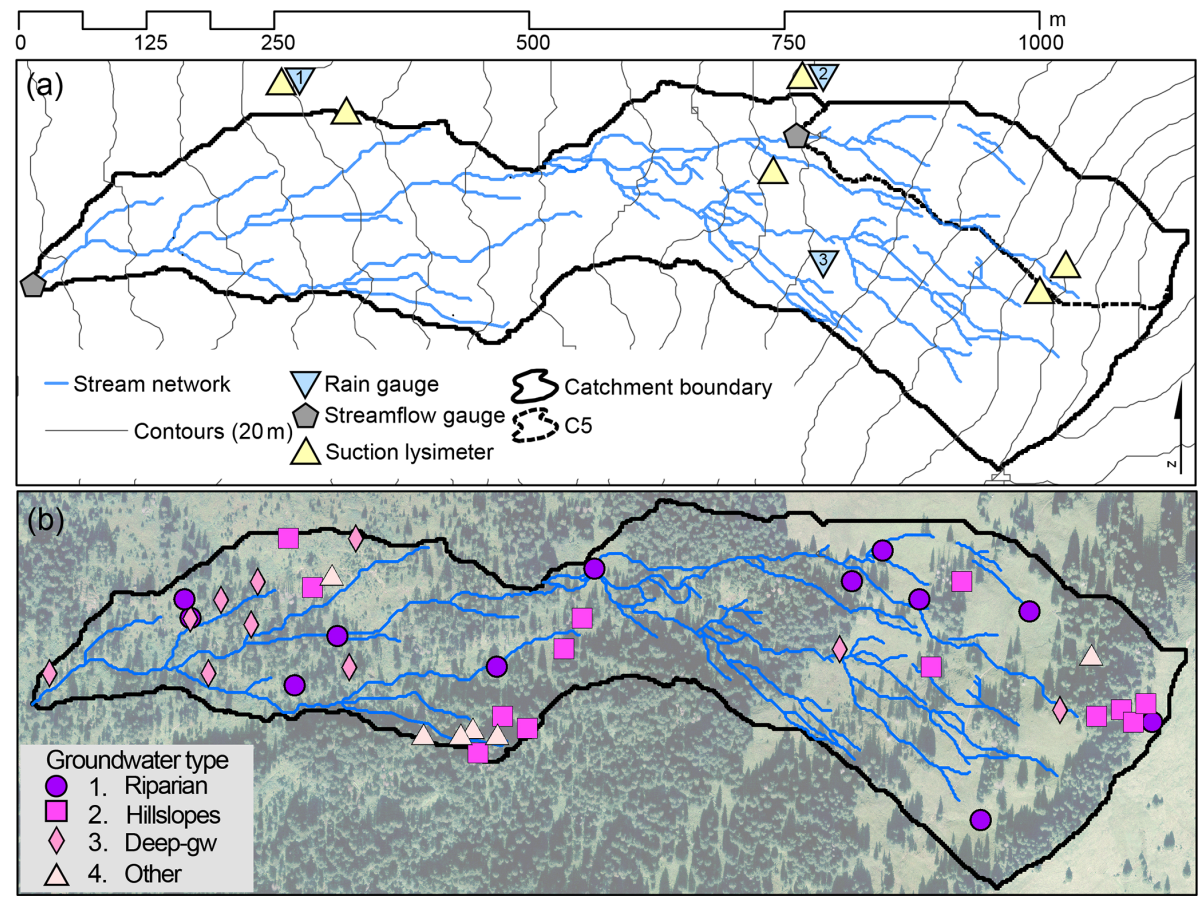

Figure 1. Maps of the Studibach catchment with (a) the stream network (blue lines), stream gauges (grey pentagons), rain gauges (blue triangles; 1-3) and suction lysimeters (yellow triangles), $20 \mathrm{~m}$ contour lines (grey), and the boundary of the catchment (black). C5 subcatchment (broken lines) and (b) location of the wells, colour-coded by groundwater type as follows: (1) riparian wells; (2) hillslope wells; (3) "deep" groundwater wells; and (4) wells with high magnesium and sulfate concentrations (based on Kiewiet et al., 2019).

with tipping-bucket rain gauges $(0.2 \mathrm{~mm}$ resolution; Odyssey Dataflow Systems Limited; Fig. 1a).

The stream stage data were converted to specific discharge ( $Q$, further referred to as discharge) using a rating curve based on 20 salt dilution measurements. Due to technical issues, there were no observations of stage height at the catchment outlet during events I and II (see Sect. 3.2). We used the correlation between the specific discharge at the catchment outlet and an intermediately sized sub-catchment (C5; Fig. 1a) for the four months following events I and II to estimate the streamflow at the outlet for the period without data (coefficient of determination $r^{2}=0.66$; RMSE $=$ $0.75 \mathrm{~mm} \mathrm{~h}^{-1}$; for comparison, the 10th and 90th percentile of $Q$ at the catchment outlet for this period were 0.35 and $2.11 \mathrm{~mm} \mathrm{~h}^{-1}$, respectively). We assume that the uncertainty in the discharge for events I and II does not affect our conclusions as they are largely based on relative changes in discharge during the events. The ranking of the events based on the peak of the (reconstructed) discharge was the same as the ranking based on the peak rainfall intensity.

\subsection{Sample collection}

We analysed streamflow and stream chemistry for four events (I-IV; Table 1) in the fall seasons of 2016 and 2017. Stream water samples were collected at the outlet of the Studibach using automatic samplers (full-size portable sampler, model no. 3712, Teledyne ISCO, USA). The sampling interval was based on the expected event duration. The multi-interval programme was set to sample stream water every 10 to $20 \mathrm{~min}$ at the start of the rising limb (maximum of six samples). The remaining 18 samples were taken at an hourly interval. We emptied the samplers within $24 \mathrm{~h}$ after sample collection to avoid fractionation. We used a timer to start the sampler if the expected time of the onset of the rainfall was during the night. Rainfall was collected with passive sequential samplers (built after Kennedy et al., 1979, and described in detail in Fischer et al., 2019) at two locations in the catchment (rain gauge location one and two in Fig. 1a). The samplers collected a sample for approximately every $5 \mathrm{~mm}$ of rainfall.

For soil water and groundwater, we used the data from a subset of nine baseflow snapshot campaigns during the snowfree seasons of 2016 and 2017 (Kiewiet et al., 2019). Soil water was collected with six to 18 suction lysimeters at four to six sites (at 15, 30 and $50 \mathrm{~cm}$ below the surface at forested and non-forested sites at three different elevations, namely 1361, 1502, $1611 \mathrm{~m}$ a.s.1.; Fig. 1a). We applied a tension of 50 mbar to the lysimeters and collected the soil water sample the next day. Groundwater was collected at all wells that contained water (34 to 38 wells). The shallow wells were either purged or at least twice the well volume was extracted a day before the sampling. For a detailed description of the groundwater sampling procedure, see Kiewiet et al. (2019). 
Table 1. Overview of the four events analysed in this study: event duration $(D, \mathrm{~h})$, rainfall amount $(P$, mm), average and maximum 10 min rainfall intensity $\left(I_{\mathrm{p}}\right.$ and $\left.I_{\mathrm{p}-\mathrm{max}}, \mathrm{mm} \mathrm{h}^{-1}\right)$, the maximum change in specific discharge $\left(\Delta Q, \mathrm{~mm} \mathrm{~h}^{-1}\right)$, the maximum change in isotopic composition of the stream water $\left(\delta^{2} \mathrm{H}, \%\right.$ ) , the minimum and maximum fraction of the catchment that was connected ( $\left.A_{\min }-A_{\max }\right)$ during the event, and the date of the groundwater and soil water sampling campaign.

\begin{tabular}{|c|c|c|c|c|c|c|c|c|c|}
\hline Event & Start date & $\begin{array}{r}D \\
(\mathrm{~h})\end{array}$ & $\begin{array}{r}P \\
(\mathrm{~mm})\end{array}$ & $\begin{array}{r}I_{\mathrm{p}} \\
\left(\mathrm{mm} \mathrm{h}^{-1}\right)\end{array}$ & $\begin{array}{r}I_{\mathrm{p}-\max } \\
\left(\mathrm{mm} \mathrm{h}^{-1}\right)\end{array}$ & $\begin{array}{r}\Delta Q \\
\left(\mathrm{~mm} \mathrm{~h}^{-1}\right)\end{array}$ & $\begin{array}{r}Q-\delta^{2} \mathrm{H} \\
(\% o)\end{array}$ & $A_{\min }-A_{\max }$ & $\begin{array}{l}\text { Date of sampling } \\
\text { campaign }\end{array}$ \\
\hline I & 2 October 2016 & 14 & 17 & 1.2 & 7 & $0.02-0.07$ & -70.5 to -65.7 & $0.27-0.48$ & 5 October 2016 \\
\hline III & 3 October 2017 & 7 & 27 & 3.9 & 24 & $0.08-0.43$ & -73.7 to -69.1 & $0.33-0.68$ & 12 October 2017 \\
\hline IV & 5 October 2017 & 27 & 32 & 1.2 & 10 & $0.07-0.30$ & -69.1 to -65.2 & $0.33-0.67$ & 12 October 2017 \\
\hline
\end{tabular}

* The fraction of the catchment that was hydrologically connected increased from 0.27 to 0.28 during the sampling period and to 0.35 during a discharge peak that occurred after the samplers stopped (see Fig. S3).

\subsection{Sample analyses}

The samples for cation and anion analyses were stored in a fridge $\left(6^{\circ} \mathrm{C}\right)$ before lab analyses (within a few days) or were frozen $\left(-18^{\circ} \mathrm{C}\right)$ directly after collection until shortly before the analyses. The samples were filtered $(0.45 \mu \mathrm{m}$; SimplepureTM syringe filter) and acidified (only for cation analysis) to mobilise trace metals. The samples were analysed at the Physics of Environmental Systems laboratory at ETH Zurich (Switzerland) using an ion chromatograph (861 Advanced Compact IC, Metrohm AG, Switzerland) for anions and a mass spectrometer (7900 ICP-MS, Agilent, USA) for cations. Calibration curves were obtained from measurements with five calibration standards before or after measuring the samples.

The samples were analysed for stable water isotope composition with a cavity ring-down spectroscope (CRDS; L2140-i or L2130-i, Picarro, Inc., USA) at the Chair of Hydrology at the University of Freiburg (Germany). The reported precision is $\pm 0.16 \%$ o for $\delta^{18} \mathrm{O}$ and $\pm 0.6 \%$ o for $\delta^{2} \mathrm{H}$. All samples plotted close to the local meteoric water line. The average ( \pm standard deviation) of the line-conditioned excess (lc excess; Landwehr and Coplen, 2006) for all 516 stream, soil and groundwater samples was $5.3 \pm 1.3 \%$, excluding five soil water samples (taken at $15 \mathrm{~cm}$ - three samples; $30 \mathrm{~cm}$ - one sample; and $50 \mathrm{~cm}$ - one sample, respectively, below the soil surface) for which lc excess ranged from -9.6 to $-1.5 \%$. Deuterium excess $\left(\mathrm{D}_{\mathrm{ex}}\right)$ was calculated as $\mathrm{D}_{\mathrm{ex}}=\delta^{2} \mathrm{H}-\left(8 \cdot \delta^{18} \mathrm{O}\right)$.

\subsection{Data analysis}

\subsubsection{Relative concentrations}

We examined the changes in stream water concentrations during the rainfall events using concentration-discharge $(C-$ $Q$ ) relationships and identified the corresponding hysteresis index (cf. Zuecco et al., 2016). For this, we normalised both the discharge and the concentrations so that 0 represents the smallest measured value, and 1 the highest measured value.
For each solute, we calculated the relative concentration $R_{x}$ by comparing the concentration of the sample to that of baseflow as follows:

$R_{x}=\frac{C_{Q \_} x}{C_{\mathrm{BF} \_} x}$,

where $C_{Q_{-} x}$ and $C_{\mathrm{BF}_{-} x}$ are the concentration of solute $x$ in stream water during the event and in baseflow before the event, respectively. We define baseflow as the streamflow between rainfall-runoff events and assume that it comes from groundwater. The relative concentration indicates dilution $\left(R_{x}<1\right)$ or enrichment $\left(R_{x} \geq 1\right)$ during the events. It thus quantifies the direction and magnitude of the change in solute concentrations (note that $R_{x}$ is not an alternative measure for the fraction of baseflow in stormflow). We used the relative concentrations $\left(R_{x} ;\right.$ Eq. 2$)$ to identify groups of solutes using hierarchical cluster analysis.

\subsubsection{Hydrograph separation and end-member mixing analysis}

We tested if the median concentrations of different (ground-)water types were significantly different (Table 2; Tukey-Kramer test; Tukey HSD test in the "agricolae" $\mathrm{R}$ package). We pairwise tested seven groups, namely all groundwater, riparian groundwater, hillslope groundwater, all soil water, soil water at forested sites, soil water at nonforested sites and rainfall. We performed all computations in R (R Core Team, 2013) and used a 95\% confidence interval for all statistical tests. We found that the soil water samples taken at forested or non-forested sites were never significantly different and thus merged these data.

We investigated the sources of streamflow using two- and three-component mixing analyses and investigated the difference between the observed solute concentrations and those estimated assuming linear mixing of baseflow and rainfall. Ideally, we would use the soil water and groundwater samples taken directly before the rainfall events, but these data are not available. Instead, we have data from sampling campaigns 2 to $9 \mathrm{~d}$ before (event II) or after the events (I, III and 
Table 2. Average concentrations ( \pm standard deviation) for all groundwater ( $\left.\mathrm{GW}_{\mathrm{avg}} ; n=335\right)$, all riparian groundwater (G1; $\left.n=99\right)$, all hillslope groundwater (G2;n=99), soil water (SW; $n=116)$, and rainfall samples $(P ; n=156)$. Solutes are ordered by their respective groups (Sect. 4.3; Fig. 6).

\begin{tabular}{|c|c|c|c|c|c|c|}
\hline Solute & Unit & $\mathrm{GW}_{\text {avg }}$ & G1 & G2 & SW & $P$ \\
\hline$\delta^{18} \mathrm{O}$ & $\% o$ & $-11.0 \pm 0.9^{b}$ & $-10.8 \pm 1.0^{\mathrm{ab}}$ & $-10.9 \pm 1.1^{\mathrm{ab}}$ & $-10.4 \pm 1.6^{\mathrm{a}}$ & $-12.3 \pm 4.0^{\mathrm{c}}$ \\
\hline$\delta^{2} \mathrm{H}$ & $\%$ & $-76.0 \pm 7.5^{b}$ & $-74.3 \pm 8.0^{\mathrm{ab}}$ & $-74.9 \pm 9.1^{\mathrm{ab}}$ & $-70.8 \pm 12.4^{\mathrm{a}}$ & $-84.4 \pm 33.0^{c}$ \\
\hline$D_{e x}$ & $\%$ & $12.0 \pm 0.8^{\mathrm{a}}$ & $12.4 \pm 0.8^{\mathrm{a}}$ & $11.8 \pm 0.9^{\mathrm{a}}$ & $12.0 \pm 2.4^{\mathrm{a}}$ & $14.1 \pm 3.2^{\mathrm{b}}$ \\
\hline $\mathrm{Cl}$ & $\mu g \mathrm{~L}^{-1}$ & $830.8 \pm 1076.5^{\mathrm{a}}$ & $708.8 \pm 570.1^{\mathrm{a}}$ & $890.5 \pm 804.9^{\mathrm{a}}$ & $1070.3 \pm 1026.6^{\mathrm{a}}$ & $327.1 \pm 348.7^{\mathrm{b}}$ \\
\hline $\mathrm{Zn}$ & $\mu \mathrm{g} \mathrm{L}^{-1}$ & $593.9 \pm 1745.7^{\mathrm{a}}$ & $720.4 \pm 2218.7^{\mathrm{a}}$ & $698.5 \pm 843.8^{\mathrm{a}}$ & $23.3 \pm 12.5^{\mathrm{b}}$ & $19.3 \pm 43.0^{\mathrm{b}}$ \\
\hline $\mathrm{Cd}$ & $\mu \mathrm{g} \mathrm{L}^{-1}$ & $0.05 \pm 0.08^{\mathrm{a}}$ & $0.0 \pm 0.1^{\mathrm{a}}$ & $0.1 \pm 0.1^{\mathrm{b}}$ & $0.03 \pm 0.06^{\mathrm{a}}$ & $0.1 \pm 0.2^{\mathrm{b}}$ \\
\hline $\mathrm{Ni}$ & $\mu \mathrm{g} \mathrm{L}^{-1}$ & $3.2 \pm 4.1^{\mathrm{d}}$ & $1.7 \pm 1.4^{\mathrm{ab}}$ & $5.6 \pm 6.6^{\mathrm{ac}}$ & $2.5 \pm 1.5^{\mathrm{ad}}$ & $0.3 \pm 0.3^{\mathrm{b}}$ \\
\hline $\mathrm{Na}$ & $\mu \mathrm{g} \mathrm{L}^{-1}$ & $1587.6 \pm 2672.7^{b}$ & $1107.1 \pm 1000.8^{\mathrm{ab}}$ & $827.6 \pm 341.3^{\mathrm{ac}}$ & $839.1 \pm 565.0^{\mathrm{bc}}$ & $148.7 \pm 153.5^{\mathrm{c}}$ \\
\hline $\mathrm{Mg}$ & $\mu \mathrm{g} \mathrm{L}^{-1}$ & $2235.7 \pm 1730.3^{\mathrm{b}}$ & $1292.5 \pm 684.3^{\mathrm{ab}}$ & $1164.1 \pm 435.6^{\mathrm{ab}}$ & $13612.8 \pm 10924^{\mathrm{c}}$ & $26.6 \pm 18.9^{\mathrm{a}}$ \\
\hline $\mathrm{Ca}$ & $\mu \mathrm{g} \mathrm{L}{ }^{-1}$ & $56993.7 \pm 21966.1^{b}$ & $44794.0 \pm 17097.6^{\mathrm{a}}$ & $55624.6 \pm 18099.0^{\mathrm{b}}$ & $22261.7 \pm 27287.8^{c}$ & $213.4 \pm 202.7^{\mathrm{d}}$ \\
\hline $\mathrm{Ba}$ & $\mu \mathrm{g} \mathrm{L}^{-1}$ & $99.2 \pm 171.6^{\mathrm{a}}$ & $64.2 \pm 115.2^{\mathrm{a}}$ & $112.3 \pm 258.6^{\mathrm{a}}$ & $37350 \pm 27637^{\mathrm{b}}$ & $4.8 \pm 11.8^{\mathrm{a}}$ \\
\hline Co & $\mu \mathrm{g} \mathrm{L}^{-1}$ & $0.8 \pm 1.05^{\mathrm{c}}$ & $1.1 \pm 1.0^{\mathrm{a}}$ & $0.3 \pm 0.2^{\mathrm{b}}$ & $0.9 \pm 1.1^{\mathrm{ac}}$ & $0.02 \pm 0.02^{\mathrm{b}}$ \\
\hline $\mathrm{Cu}$ & $\mu \mathrm{g} \mathrm{L}^{-1}$ & $64.9 \pm 143.7^{\mathrm{c}}$ & $7.4 \pm 16.1^{\mathrm{a}}$ & $175.5 \pm 211.8^{\mathrm{b}}$ & $5.2 \pm 9.0^{\mathrm{a}}$ & $1.4 \pm 1.0^{\mathrm{a}}$ \\
\hline $\mathrm{SO}_{4}$ & $\mu \mathrm{g} \mathrm{L}^{-1}$ & $3600.0 \pm 5112.5^{\mathrm{b}}$ & $2511.6 \pm 2843.2^{\mathrm{ab}}$ & $2418.7 \pm 1848.2^{\mathrm{ab}}$ & $1602.0 \pm 3061.9^{\mathrm{a}}$ & $623.1 \pm 980.1^{\mathrm{c}}$ \\
\hline $\mathrm{K}$ & $\mu \mathrm{g} \mathrm{L}^{-1}$ & $530.1 \pm 428.0^{\mathrm{c}}$ & $328.3 \pm 219.2^{\mathrm{a}}$ & $670.3 \pm 543.4^{\mathrm{bc}}$ & $754.1 \pm 970.8^{\mathrm{b}}$ & $92.2 \pm 91.9^{\mathrm{d}}$ \\
\hline $\mathrm{Fe}$ & $\mu g \mathrm{~L}^{-1}$ & $390.7 \pm 1271.1^{\mathrm{a}}$ & $608.3 \pm 1648.4^{\mathrm{a}}$ & $25.4 \pm 38.6^{\mathrm{b}}$ & $254.3 \pm 775.9^{\mathrm{ab}}$ & $3.5 \pm 7.1^{\mathrm{b}}$ \\
\hline Mn & $\mu \mathrm{g} \mathrm{L}^{-1}$ & $592.4 \pm 1111.6^{\mathrm{c}}$ & $1007.8 \pm 911.3^{\mathrm{a}}$ & $68.4 \pm 100.5^{\mathrm{b}}$ & $139.9 \pm 326.2^{\mathrm{b}}$ & $1.3 \pm 1.4^{\mathrm{b}}$ \\
\hline
\end{tabular}

Different superscript letters $\left({ }^{\mathrm{a}-\mathrm{d}}\right)$ indicate significantly different average concentrations.

IV). Since the spatial variability in groundwater composition in the Studibach is larger than the temporal variability (Kiewiet et al., 2019), we assume that the groundwater and soil water samples reflect the typical composition and variability of soil water and groundwater but acknowledge that absolute concentrations might have been slightly different. A principal component analysis (PCA) on the chemical and isotopic composition of all groundwater $(n=335)$ and soil water $(n=116)$ samples ( $z$ transformed) showed that soil water and groundwater were consistently different in the principal component space; only six of the soil water samples $(5 \%)$ plotted within the same area as the groundwater samples (see Fig. S1 in the Supplement for the PCA result and Table 2 for the average concentrations).

We estimated the fraction of event $\left(f_{\mathrm{e}}\right)$ and pre-event $\left(f_{\mathrm{pe}}\right)$ water in the stream water samples $\left(C_{\mathrm{t}}\right)$ using two-component isotope hydrograph separation (Eq. 2). The results for $\delta^{2} \mathrm{H}$ and $\delta^{18} \mathrm{O}$ were similar (difference between the event average $f_{\mathrm{pe}} \leq 0.05$ ). Because the ratio of precision to range was better for $\delta^{2} \mathrm{H}$, we report only the $\delta^{2} \mathrm{H}$ results. A pre-event baseflow sample was used to characterise the pre-event water composition $\left(C_{\mathrm{pe}}\right)$. The incremental weighted mean of rainfall was used to characterise the event water composition $\left(C_{\mathrm{e}}\right)$.

$f_{\mathrm{pe}}=\frac{C_{\mathrm{t}}-C_{\mathrm{e}}}{C_{\mathrm{pe}}-C_{\mathrm{e}}}$.

We also estimated the fractions of groundwater, soil water and rainwater in each stream water sample using a three- component end-member mixing analysis (EMMA; Christophersen and Hooper, 1992). We based the EMMA on the first two principal components of a PCA that included all conservative tracers. We considered a tracer conservative if the concentration was linearly correlated to that of at least one other tracer (cf. Barthold et al., 2011). To determine the conservativeness, we used all groundwater, soil water and stream water samples used in this study $(n=549)$ and set the threshold for a linear correlation to $R^{2} \geq 0.5$ and $p<0.01$. Electrical conductivity (EC), calcium, magnesium, barium, $\delta^{2} \mathrm{H}$ and $\delta^{18} \mathrm{O}$ were conservative based on this definition; the other tracers (e.g. copper, sulfate, potassium and iron) were not. However, note that this threshold does not per se imply a linear trend, and that although a linear trend is consistent with conservative mixing, it does not necessarily confirm conservative mixing either (James and Roulet, 2006).

We used a Gaussian error propagation method (Genereux, 1998) to estimate the uncertainty in the calculated fractions of the source waters for the two-component hydrograph separation and EMMA. For the two-component hydrograph separation, we defined the uncertainty in the event and pre-event water composition as the standard deviation of the rainfall sampled during the event and groundwater sampled during the snapshot campaign closest to the event (see Table 1), respectively. For the uncertainty in the EMMA, we used the standard deviation of groundwater, soil water and rainwater samples for the event. We used the laboratory accuracy for the uncertainty of the stream water samples in the twocomponent hydrograph separation, and for the EMMA we 
assumed that the uncertainty for the stream water samples in the principal component space was similar to the standard deviation of the last three stream water samples taken during each event (i.e. the last streamflow samples taken at the falling limb of the hydrograph). We multiplied the standard deviation with a $t$ value based on the number of samples and used a $95 \%$ confidence interval for all uncertainty estimations.

\subsubsection{Deviation of concentrations from mixing of baseflow and rainfall}

We compared the measured streamflow concentrations for each solute to the concentration that would be expected based on conservative mixing of rainfall and baseflow $\left(C_{\mathrm{es}}\right)$ as follows:

$C_{\text {es } \_x}=\left(C_{\mathrm{BF} \_x} \cdot f_{\mathrm{pe}}\right)+\left(C_{\mathrm{P} \_x} \cdot\left(1-f_{\mathrm{pe}}\right)\right)$,

where $C_{\text {es } \_x}$ is the "estimated" concentration for solute $x$, $C_{\mathrm{BF} \_x}$ and $C_{\mathrm{P}_{-} x}$ are the concentrations for solute $x$ in baseflow and rainfall (average rainfall composition - Table 2), and $f_{\mathrm{pe}}$ is the pre-event water fraction for that sample as determined from the two-component hydrograph separation using $\delta^{2} \mathrm{H}$ as the tracer (Eq. 2).

We compared the estimated $\left(C_{\text {es } \_x}\right)$ and measured streamflow $\left(C_{Q_{-} x}\right)$ concentrations for each sample and solute to assess the relationship between discharge and the potential contribution of different source areas. We assumed that underestimation of the concentrations $\left(C_{Q_{-} x} / C_{\mathrm{es} \_x}>1\right)$ indicates either a contribution from source areas that have a higher concentration than the sources that contributed to baseflow or reactive transport. Similarly, overestimation of the concentrations $\left(C_{Q_{-} x} / C_{\text {es } \_x}<1\right)$ indicates either a contribution from source areas that did not contribute during baseflow and have a lower concentration than the sources that contributed to baseflow or reactive transport. Given the characteristic concentrations in different (ground-)water types (Tables 2 and 3; Fig. 2), we interpret the changes in the stream water composition during an event as follows: (1) higher copper and nickel concentrations are indicative of contributions from hillslopes and forested areas, (2) higher iron and manganese concentrations are indicative of contributions from riparian areas, (3) higher $D_{\text {ex }}$, barium, and magnesium concentrations are indicative of soil water, and (4) higher potassium concentrations can indicate either soil water or hillslopes groundwater. However, note that the variability for soil water, groundwater and rainfall was large (Table 2; see Fig. S2 for boxplots of tracer concentrations in each water compartment). Also, the non-conservative nature of these tracers should be taken into account. For instance, iron and manganese are mainly soluble under anoxic, reducing conditions, such as in the riparian areas, but they might oxidise and form an insoluble compound after entering the streams. Adsorption of metals (e.g. iron, copper and zinc) to organic compounds or clay particles may also influence the concentrations in streamflow,

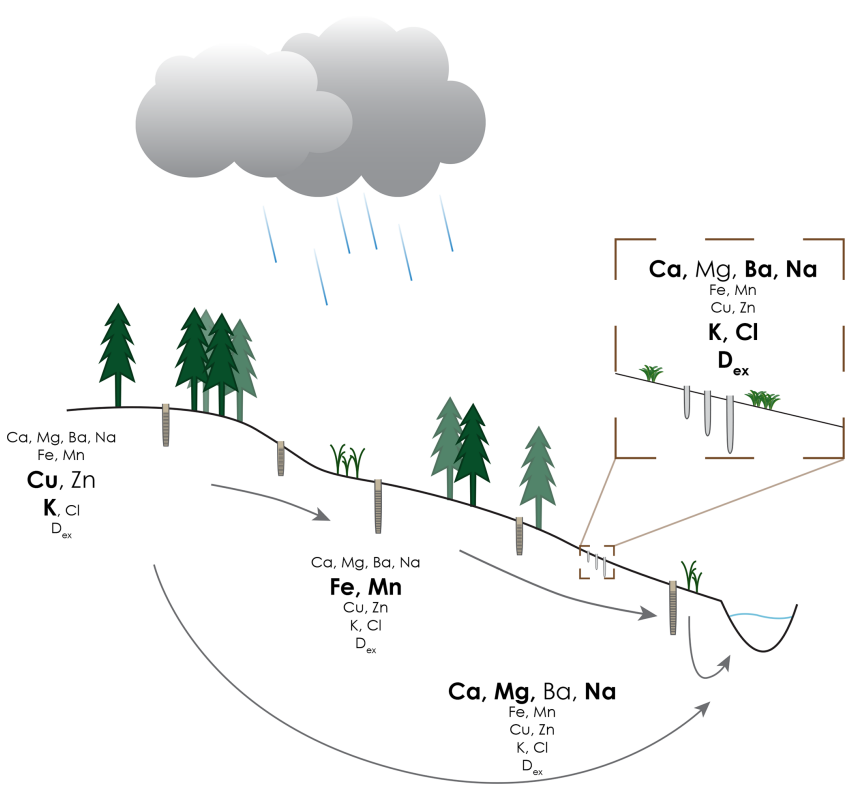

Figure 2. Illustration of a hillslope cross section with different (ground-)water compartments (based on Kiewiet et al., 2019 and Table 2), showing the tracers used in combination with $\delta^{2} \mathrm{H}$ and $\delta^{18} \mathrm{O}$ to characterise the different source areas. For most elements, the concentrations were low in rainfall compared to the concentrations in the other water compartments. High potassium, barium and chloride concentrations and high deuterium excess $\left(D_{e x}\right)$ are indicative of soil water. For shallow groundwater, the concentrations of copper and potassium were higher at (forested) ridge locations, whereas for sites with water tables that are persistently close to the surface, the concentrations of iron and manganese were higher. We assume that higher concentrations of geogenic solutes (calcium, magnesium and sodium) indicate longer subsurface residence times. The isotopic composition for the different water compartments depends on the composition of recent precipitation.

and their concentration may be underestimated if they are adsorbed to coarser particles that settle out during streamflow recession (Kaushal et al., 2018). The concentration of some solutes is, furthermore, controlled by weathering processes or influenced by plant uptake because they are macro (potassium and magnesium) or micro (e.g. copper and nickel) plant nutrients. In this study, we assume that concentration increases or decreases due to weathering or plant uptake are negligible at the event (i.e. hourly) timescale.

\subsubsection{Groundwater-level-based connectivity assessment}

We investigated into how far stream chemistry reflects conservative mixing of baseflow and precipitation and whether this breaks down at a certain discharge or reflects an increase in hydrologic connectivity. We related the ratio of the measured and estimated concentrations $\left(C_{Q_{-} x} / C_{\text {es_x } x}\right.$, see Sect. 3.4.3) for each solute to the discharge and the calculated fraction of the catchment that was connected to the stream. We used the data-driven model of Rinderer et al. (2019) to 
Table 3. Summary of the groups of the solutes (A-D, based on the relative concentrations during all four events; Fig. 6; NG indicates that this solute is not assigned to a group), the typical response of solute concentrations to increasing discharge $(++$ : strong enrichment, mean $R_{x}>1.5$; + : enrichment, mean $R_{x}$ between 1 and 1.5 ; - : dilution, and mean $R_{x}<1 ; \pm$ : mixed response), and ratios between the average concentrations in soil water $\left(C_{\mathrm{SW}}\right)$ and groundwater $\left(C_{\mathrm{GWavg}}\right)$ as well as the groundwater from riparian wells $\left(C_{\mathrm{G} 1}\right)$ and hillslope wells $\left(C_{\mathrm{G} 2}\right.$; see Table 2$)$. See Figs. 5 and 6 for example concentration-discharge relationships for each group of solutes. The solutes are sorted according to their typical response.

\begin{tabular}{llcrr}
\hline Solute & Group & $\begin{array}{c}\text { Typical }(C) \\
\text { response to } \\
\text { increasing } Q\end{array}$ & $C_{\mathrm{SW}} / C_{\mathrm{GWavg}}$ & $C_{\mathrm{G} 2} / C_{\mathrm{G} 1}$ \\
\hline $\mathrm{D}$ ex & $\mathrm{NG}$ & ++ & 1 & \\
$\mathrm{Cl}$ & $\mathrm{NG}$ & ++ & 1.3 & 1.3 \\
$\mathrm{Fe}$ & $\mathrm{D}$ & + & 0.7 & $\sim 0$ \\
$\mathrm{Mn}$ & $\mathrm{D}$ & + & 0.2 & 0.1 \\
$\mathrm{Co}$ & $\mathrm{C}$ & \pm & 1.1 & 0.3 \\
$\mathrm{Cu}$ & $\mathrm{C}$ & \pm & 0.1 & 23.7 \\
$\mathrm{SO} 4$ & $\mathrm{C}$ & \pm & 0.4 & 1 \\
$\mathrm{~K}$ & $\mathrm{C}$ & \pm & 1.4 & 2 \\
$\mathrm{Cd}$ & $\mathrm{A}$ & \pm & 0.6 & - \\
$\mathrm{Zn}$ & $\mathrm{A}$ & \pm & 0 & 1 \\
$\mathrm{Ni}$ & $\mathrm{NG}$ & \pm & 0.8 & 3.3 \\
$\mathrm{Na}$ & $\mathrm{B}$ & - & 0.5 & 0.7 \\
$\mathrm{Mg}$ & $\mathrm{B}$ & - & 6.1 & 0.9 \\
$\mathrm{Ca}$ & $\mathrm{B}$ & - & 0.4 & 1.2 \\
$\mathrm{Ba}$ & $\mathrm{B}$ & - & 376.5 & 1.7 \\
\hline
\end{tabular}

determine which parts of the catchment were active and connected to the stream. This model uses the water level data from all 51 wells in the catchment and time series clustering to assign each pixel in the catchment to one of six groundwater level clusters based on topography. For each time step, the average relative groundwater level for all monitoring wells that belong to a cluster is calculated and assigned to all pixels in that cluster. This relative water level is then transformed into an absolute water level based on the correlation between soil depth and slope. If this simulated water level is within $30 \mathrm{~cm}$ of the soil surface (i.e. the part of the soil where the hydraulic conductivity is high), the pixel is considered active; otherwise, it is considered inactive. If a pixel is active and, based on surface topography, connected to the stream via other active pixels, it is assumed to be connected to the stream. We thus assume that significant lateral flow occurs when the water table rises into the near-surface layers where the hydraulic conductivity is much larger (cf. Schneider et al., 2014). Hence, the simulated connectivity refers to the connectivity of groundwater flow in the more permeable layer of the soil above the more permanently saturated soil. In the Studibach, there is an almost permanent water table in the low-conductivity gleysols in most locations. It is thus not so likely that the lateral water flow would infiltrate into the bedrock before reaching the stream (Jackson et al., 2014). Rinderer et al. (2019) tested the sensitivity of the method for misclassification of the clusters by randomly reassigning pixels to different clusters and the uncertainty in the soil depth by comparing the connectivity time series to the time series computed with a different (DEM-based) soil depth map. The soil depth had only a minor influence on the model results (RMSE $>0.0003 \%$ of the relative soil depth). Still, misclassification of pixels (i.e. assigning them to a different cluster) could result in a difference of up to $8 \%$ in the simulated connected area between the different model runs.

\section{Results}

\subsection{Event characteristics}

Total rainfall for the four events ranged between 17 and $33 \mathrm{~mm}$ (Table 1; Fig. 3). The duration of the events ranged from 7 to $28 \mathrm{~h}$. The four events were larger than the longterm average daily precipitation and within the upper 30th percentile of daily precipitation at the long-term meteorological station Erlenhöhe, located $500 \mathrm{~m}$ from the catchment outlet (median $-10.0 \mathrm{~mm}$; mean $\pm \mathrm{SD}-14.1 \pm 13.8 \mathrm{~mm}$ for all $7452 \mathrm{~d}$ with more than $1 \mathrm{~mm}$ of precipitation between 1981-2017; Stähli, 2018). However, the events were smaller than the $50 \mathrm{~mm}$ threshold for large contributions of event water to streamflow (Fischer et al., 2017). The average and maximum 10 min rainfall intensities ranged between 1.2 and $3.9 \mathrm{~mm} \mathrm{~h}^{-1}$ and between 7 and $24 \mathrm{~mm} \mathrm{~h}^{-1}$, respectively.

Discharge at the catchment outlet increased the least (from 0.02 to $0.07 \mathrm{~mm} \mathrm{~h}^{-1}$ ) for the smallest event (I) and most for event III $\left(0.08\right.$ to $\left.0.43 \mathrm{~mm} \mathrm{~h}^{-1}\right)$. The simulated fraction of the catchment that was hydrologically connected to the stream varied from 0.27 (before the start of events I and II) to 0.68 (at the time of peak flow for event III; Fig. 4). The relationship between the simulated fraction of the catchment that was connected to the stream and discharge was non-linear for all events (Fig. 5, top row). For all of the four events, connectivity was lower on the rising limb of the hydrograph than on the falling limb for the same discharge. For event I, the connected area increased significantly at the recession of the streamflow. For event II, connectivity increased little during the sampling period ( 0.27 to 0.28$)$. Discharge increased to $>4 \mathrm{~mm} \mathrm{~h}^{-1}$ after the sampling period of event II due to additional rainfall, but interestingly the simulated connectivity increased only marginally (up to 0.35 ; see Fig. S3) during this period. During the smaller events with initially low connectivity, the hydrologically connected area extended laterally from the stream up but remained confined to the flat areas. For the intermediate events (III and IV), the lateral extension was larger and parts of the hillslopes became connected. However, the data-based model suggested that during all four events, large parts of the catchment remained hydrologically disconnected from the stream network (Table 1; Fig. 4). 

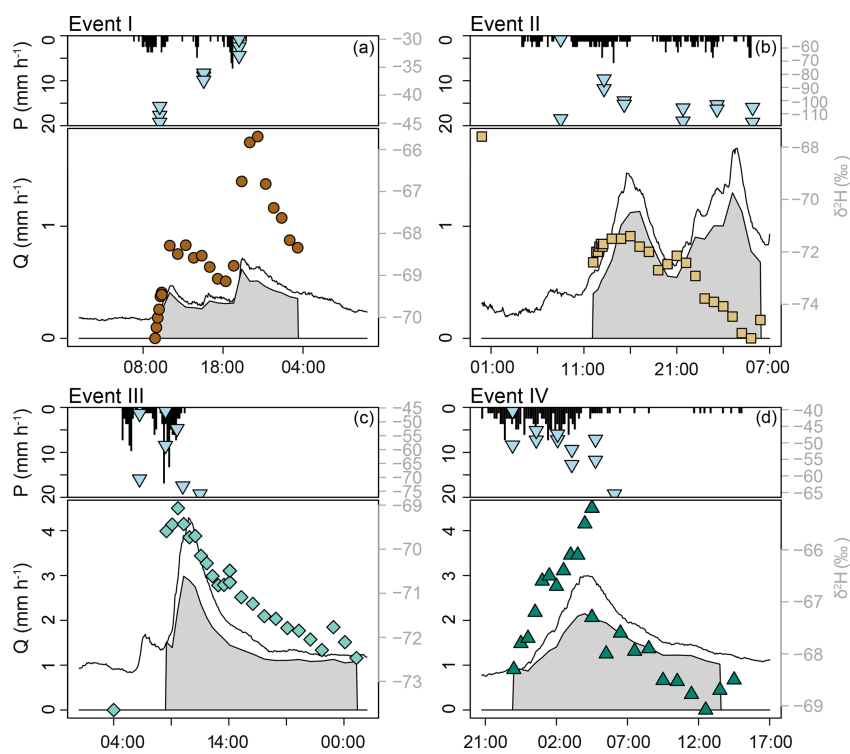

Figure 3. Hydrographs and hyetographs for the four studied events (I-IV). For each event, the upper panel shows the $10 \mathrm{~min}$ rainfall intensity $\left(\mathrm{mm} \mathrm{h}^{-1}\right.$; bar graph) and the isotopic composition of the rainfall ( $\delta^{2} \mathrm{H}$ in $\%$; light blue triangles), while the lower panel shows the discharge at the catchment outlet $\left(\mathrm{mm} \mathrm{h}^{-1}\right.$; solid line), the isotopic composition of stream water $\left(\delta^{2} \mathrm{H}\right.$ in \%o; brown dots, light brown squares, turquoise diamonds and green triangles for events I-IV, respectively), and the pre-event water fraction of streamflow based on two-component hydrograph separation using $\delta^{2} \mathrm{H}$ (grey polygon) as a tracer.

\subsection{Concentration-discharge relationships}

The chemical and isotopic composition of stream water changed during all four events, but the magnitude and direction of the response differed for each event and solute (Fig. 5). Hysteresis in the relationship between solute concentrations and discharge depended on the event size and differed between solutes (Table 3; Fig. 5). During events III and IV, the relationship between discharge and concentration was hysteretic for most solutes. The double discharge peaks during events I and II (Fig. 2) resulted in a double loop in the concentration-discharge relationship for deuterium, iron and calcium (Fig. 5).

The average relative concentration (average $R_{x}$ for the streamflow samples taken during the four events, $n=100$; Eq. 1) for deuterium excess $\left(D_{\mathrm{ex}}\right)$ and chloride was 4.1 and 2.0 , respectively. This reflects the substantial increase in these concentrations during events. Manganese and iron concentrations also increased with increasing discharge but less than $\mathrm{D}_{\mathrm{ex}}$ and chloride (mean $R_{x}-1.0$ for both iron and manganese; maximum $R_{x}-2.8$ and 3.2, respectively). On average, the concentrations of copper, nickel and zinc decreased with increasing discharge (mean $R_{x}-0.78,0.63$ and 0.31 ), but individual stormflow samples were enriched up to 1.7 , 1.3 and 1.1 times the baseflow concentration, respectively.
Table 4. Event-average pre-event water fraction $\left(f_{\text {pe }}\right)$ based on the two-component hydrograph separation using $\delta^{2} \mathrm{H}$ as a tracer, and the event-average fractions of groundwater $\left(f_{\mathrm{GW}}\right)$, soil water $\left(f_{\mathrm{SW}}\right)$ and rain water $\left(f_{\mathrm{P}}\right)$ based on the three-component end-member mixing analyses and the associated uncertainties for both calculations.

\begin{tabular}{|c|c|c|c|c|c|c|}
\hline \multirow[t]{2}{*}{ Event } & \multicolumn{2}{|c|}{ Two component } & \multicolumn{4}{|c|}{$\begin{array}{l}\text { Three-component end-member } \\
\text { mixing analyses }\end{array}$} \\
\hline & $f_{\mathrm{pe}}$ & Uncertainty & $f_{\mathrm{GW}}$ & $f_{\mathrm{SW}}$ & $f_{\mathrm{P}}$ & Uncertainty \\
\hline I & 0.86 & 0.28 & 0.81 & $\sim 0$ & 0.19 & 0.16 \\
\hline II & 0.76 & 0.61 & 0.49 & 0.27 & 0.24 & 0.14 \\
\hline III & 0.81 & 0.69 & 0.72 & 0.01 & 0.27 & 0.16 \\
\hline IV & 0.78 & 0.25 & 0.74 & 0.01 & 0.25 & 0.14 \\
\hline
\end{tabular}

Concentrations of iron and copper were higher on the falling limb than on the rising limb (anticlockwise hysteresis). Event I was the only event during which copper concentrations did not increase with increasing discharge.

The concentrations of sodium, magnesium, calcium and barium decreased with increasing discharge (mean $R_{x}$ $<0.77$ ). The concentrations of these solutes, and also sulfate, were higher on the rising limb than on the falling limb (resulting in clockwise hysteresis). Sulfate concentrations decreased with increasing discharge during events I, III and IV but increased with discharge during event II. Potassium and sulfate concentrations (range $R_{x}-0.2-1.7$ and $0.3-1.4$, respectively) were highest shortly after the onset of an event (first four samples) and decreased afterwards. These differences in the magnitude and timing of the change in solute concentrations and isotopic composition allowed for subdivision of the tracers into four different groups based on the computed $R_{x}$ values for all events (A to D; Table 3; Fig. 6).

\subsection{Hydrograph separation and end-member mixing analysis results}

Two-component hydrograph separation indicated that most stormflow was "old" water (Fig. 3; Table 3). The maximum event water fraction $\left(f_{\mathrm{e}}\right)$ was highest for event II $\left(f_{\mathrm{e}}=\right.$ $0.24 \pm 0.61)$ and lowest for event IV $\left(f_{\mathrm{e}}=0.14 \pm 0.28\right)$. However, the differences between the events were much smaller than the associated uncertainties (Table 4). The high event water fraction of event II occurred when the connected area was relatively small. The fraction of connected area during event II expanded by only 0.01 (up to 0.28 ) during the period that we sampled (see Fig. S3).

It was possible to calculate the relative fractions of groundwater, soil water and rainwater in stormflow for all events based on EMMA as well (Table 4). Groundwater dominated streamflow during all events (range $f_{\mathrm{GW}}-0.49 \pm 0.14$ to $0.81 \pm 0.19)$. The event-average soil water fraction was considerable during event II $\left(f_{\mathrm{SW}}-0.27\right)$ but negligible during the other events $\left(f_{\mathrm{SW}}-\sim 0\right)$. The event-average pre-event water fractions based on the EMMA (i.e. the sum of the 


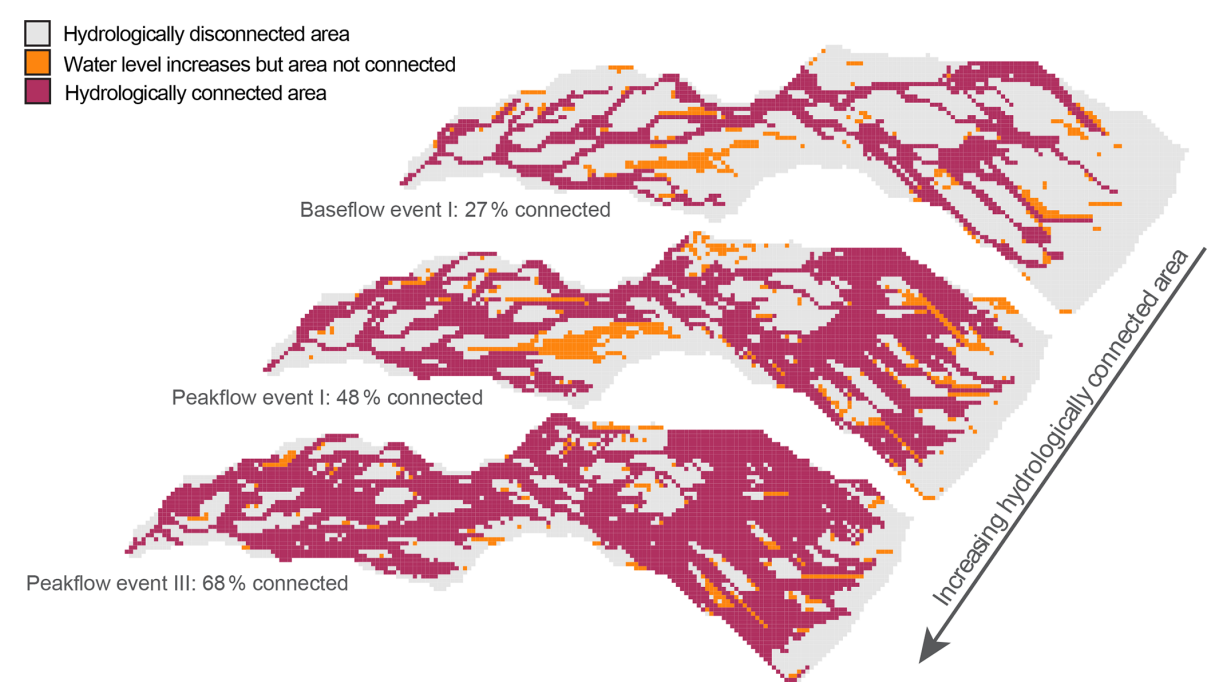

Figure 4. The simulated hydrologically connected area for three different flow conditions: from relatively low flow (baseflow prior to event I; top) and intermediate flow conditions (peak flow during event I; middle) to the period of highest discharge for the studied events (peak flow during event III; bottom). Grey indicates the hydrologically disconnected areas (water level more than $30 \mathrm{~cm}$ from the soil surface), red indicates the hydrologically connected area (i.e. water level within $30 \mathrm{~cm}$ from the soil surface and connected to the stream via other active areas), and orange indicates the active but disconnected area (i.e. the water level increased into the upper $30 \mathrm{~cm}$ of the soil but is not connected to the stream network by other active areas). The connected area was simulated based on the measured groundwater levels and a data-driven model that uses surface topography to estimate the water level for unmonitored grid cells (cf. Rinderer et al., 2019).

groundwater and soil water fractions) were similar to the preevent water fractions estimated using $\delta^{2} \mathrm{H}$ as a tracer in the two-component hydrograph separations (range $f_{\mathrm{GW}}+f_{\mathrm{SW}}-$ 0.73 to 0.81 versus range $f_{\mathrm{pe}}-0.76$ to 0.86 ). Although the results were similar, the uncertainties for EMMA were smaller than for the two-component hydrograph separation. The uncertainties for the EMMA results were mainly caused by the uncertainty in the groundwater fraction (contribution of the groundwater uncertainty to the total uncertainty $-97 \%$, $50 \%, 94 \%$ and $94 \%$ for events I-IV, respectively). This is due to the large contribution of groundwater to streamflow and the large spatial variability in the groundwater composition. For event II, the uncertainty due to the soil water contributions was larger than for the other events ( $25 \%$ for event II versus $0.01 \%, 3 \%$ and $5 \%$ for event I, III and IV, respectively).

The explanatory power of the first two principal components for all stormflow, soil water and groundwater samples was $76.3 \%$ for event I (PC1 - 53.1\%; PC2 - 23.2\%) and $82.0 \%$ for event III (PC1 $-56.2 \%$; PC2 $-25.8 \%$; Fig. $7 \mathrm{a}$ and c). For event II and IV the explanatory power was $72.6 \%$ and $83.8 \%$, respectively (see Fig. S4). The most striking aspect of the mixing plots, however, is the small change in the composition of stormflow compared to the spatial variation in the composition of the soil and groundwater end members (Fig. 7b and d). The observed changes in solute concentrations in streamflow were largest during event II (e.g. changes of $23 \mu \mathrm{g} \mathrm{L}^{-1}$ for Ba; $39 \mathrm{mg} \mathrm{L}^{-1}$ for $\mathrm{Ca}$ and $11 \%$ or $\delta^{2} \mathrm{H}$ ) but this change was similar to or smaller than the standard devi- ation of the concentrations for the groundwater samples or soil water samples taken during the corresponding snapshot campaign (e.g. groundwater $-44 \mu \mathrm{g} \mathrm{L}^{-1}$ for Ba, $27 \mathrm{mg} \mathrm{L}^{-1}$ for $\mathrm{Ca}$ and $5.9 \%$ for $\delta^{2} \mathrm{H}$; soil water $-22310 \mu \mathrm{g} \mathrm{L}-1$ for Ba, $23 \mathrm{mg} \mathrm{L}^{-1}$ for $\mathrm{Ca}$ and $10.4 \%$ o for $\delta^{2} \mathrm{H}$; see Fig. S2 for boxplots of the concentrations for the different water types).

\subsection{Estimated solute concentrations based on conservative mixing of rainfall and baseflow}

The concentrations estimated based on the assumption of conservative mixing between rainfall and baseflow $\left(C_{\mathrm{es}}\right.$; Eq. 3) differed from the measured stormflow concentrations $\left(C_{Q}\right)$ for almost all solutes (Fig. 8). The measured concentrations for geogenic solutes (shown for calcium and sodium in Fig. 8) were lower than the estimated concentrations. The measured concentrations of sulfate were lower than estimated based on conservative mixing as well, except for event II. For potassium there was no clear pattern; the concentrations were underestimated and overestimated at both low and high discharge (Fig. 8). The measured concentrations of cobalt, copper, nickel and iron (solute groups A and C; see Fig. 6) were slightly lower than the estimated concentrations for low discharge but (much) higher during high discharge (Fig. 8). There was no distinct threshold in the relationship between $C_{Q} / C_{\text {es }}$ and either the discharge or the simulated fraction of the catchment that was connected to the stream (Figs. 8 and S5); $C_{Q} / C_{\mathrm{es}}$ rather changed gradually with increasing discharge and connected area. 


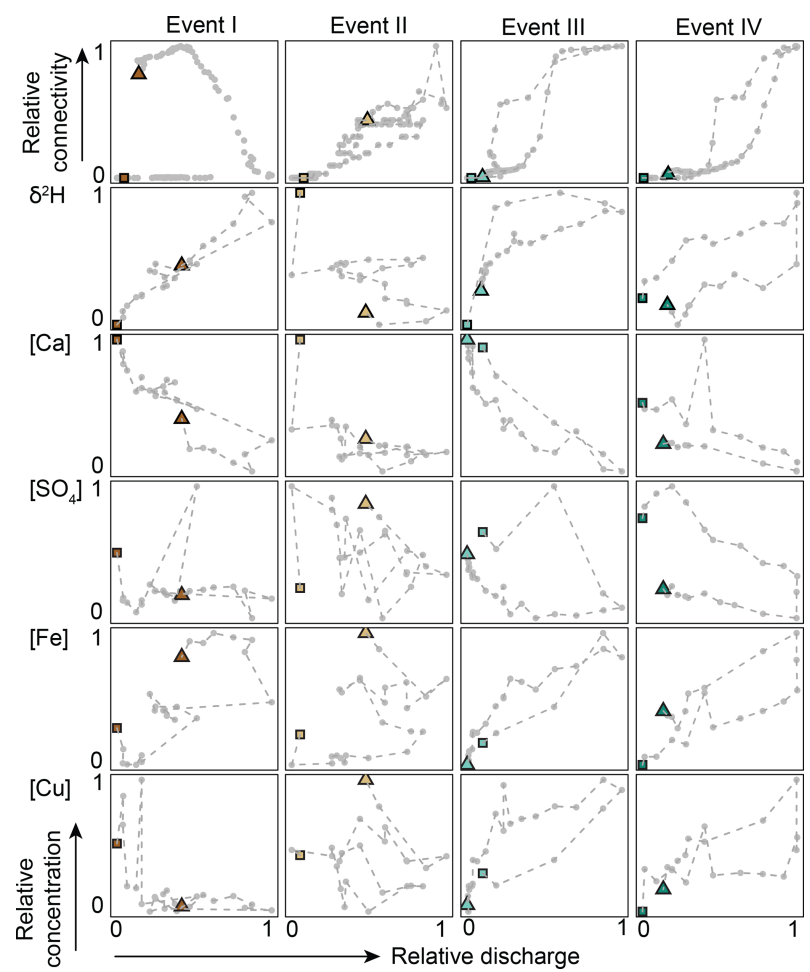

Figure 5. Relationship between the fraction of the catchment that was connected (relative connectivity) and discharge (top row), and concentration-discharge relationships for $\delta^{2} \mathrm{H}$, calcium, sulfate, iron and copper (rows 2-6) for events I-IV (columns). Individual samples are marked with a grey dot and connected with a broken line. The first sample of the event is indicated by a square and the last sample by a triangle. All data are normalised between 0 (minimum measured value for the event) and 1 (maximum measured value for the event) for better visualisation of the hysteretic relationship.

\section{Discussion}

\subsection{Small changes in streamflow composition compared to the spatial variability in groundwater and soil water}

Changes in solute concentrations in stream water during rainfall events depend on the changes in the relative contributions of different sources to streamflow (e.g. event and pre-event water or different pre-event water sources), the differences in the concentrations of these sources, as well as reactive transport processes. Our results show that the change in streamflow composition during the four rainfall events was much smaller than the spatial variability in groundwater and soil water composition. For instance, the average change in the concentration of barium and deuterium in streamflow for the four events was similar to the spatial variability in shallow groundwater and soil water measured after events I and II $\left(13.8 \mu \mathrm{g} \mathrm{L}^{-1} \mathrm{Ba}\right.$ and $6.1 \%$ change in stream water, versus an interquartile range of $30 \mu \mathrm{g} \mathrm{L}^{-1}$ and $4.8 \%$ for shallow

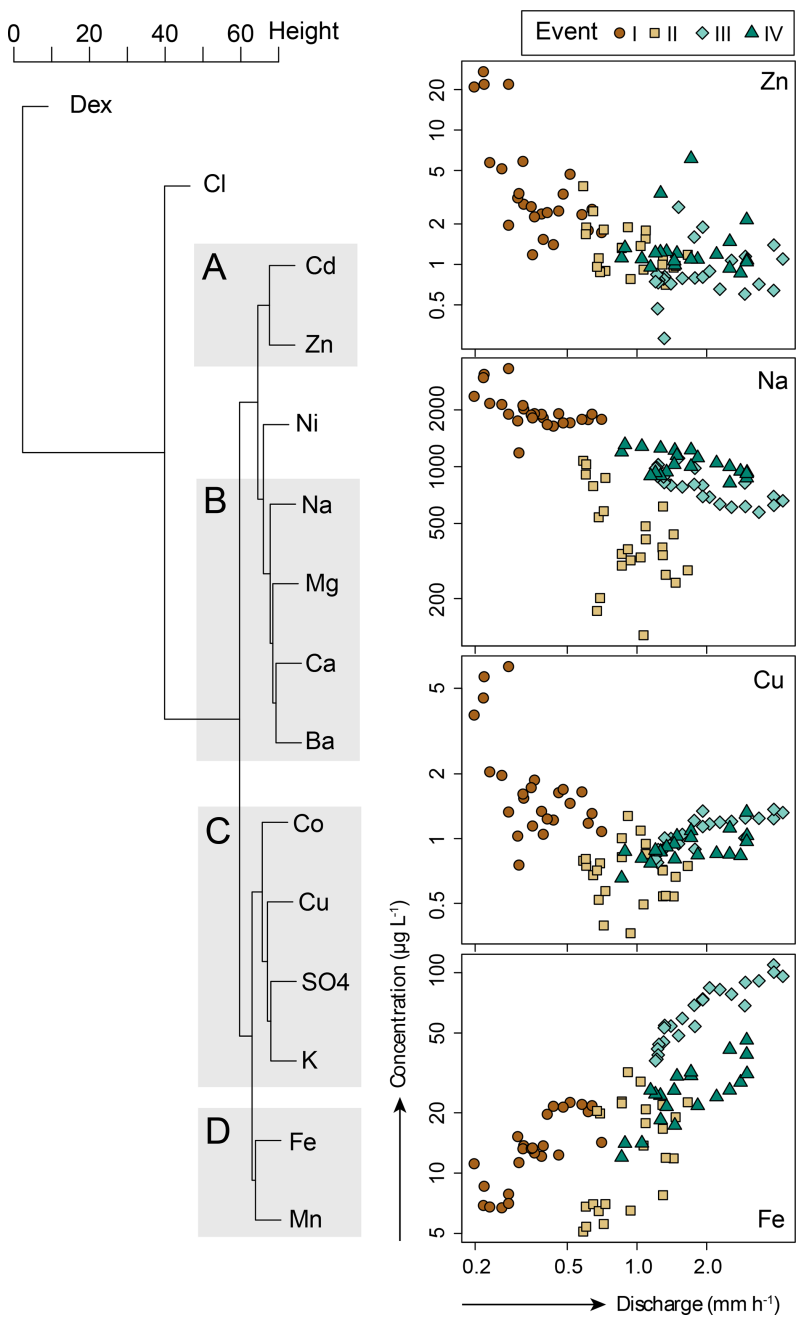

Figure 6. Dendrogram for the hierarchical clustering of solutes and $\mathrm{D}_{\mathrm{ex}}$ based on the magnitude and timing of changes in streamflow concentrations compared to the baseflow concentration $\left(R_{x} ;\right.$ Eq. 2$)$ during the four events (I-IV), and concentration-discharge relationships for one solute from each group (A-D).

groundwater and $10.6 \mathrm{mg} \mathrm{L}^{-1}$ and $5.7 \%$ in soil water). This was also evident from the principal component analysis and mixing plots (Fig. 7). It is to be expected that the change in stream water composition is less than the variability between the end members, but for a viable hydrograph separation, the change in stream water composition should be larger than the variability within the end members (Hooper, 2001). The change in stream water composition during the four events presented in this study was not large enough to distinguish contributions from the different groundwater sources, although it is evident that pre-event water dominated streamflow.

We could show that the spatial variation within different source areas was large compared to the temporal variation because we collected a large dataset of groundwater and soil water samples. However, in other small catchment studies, 


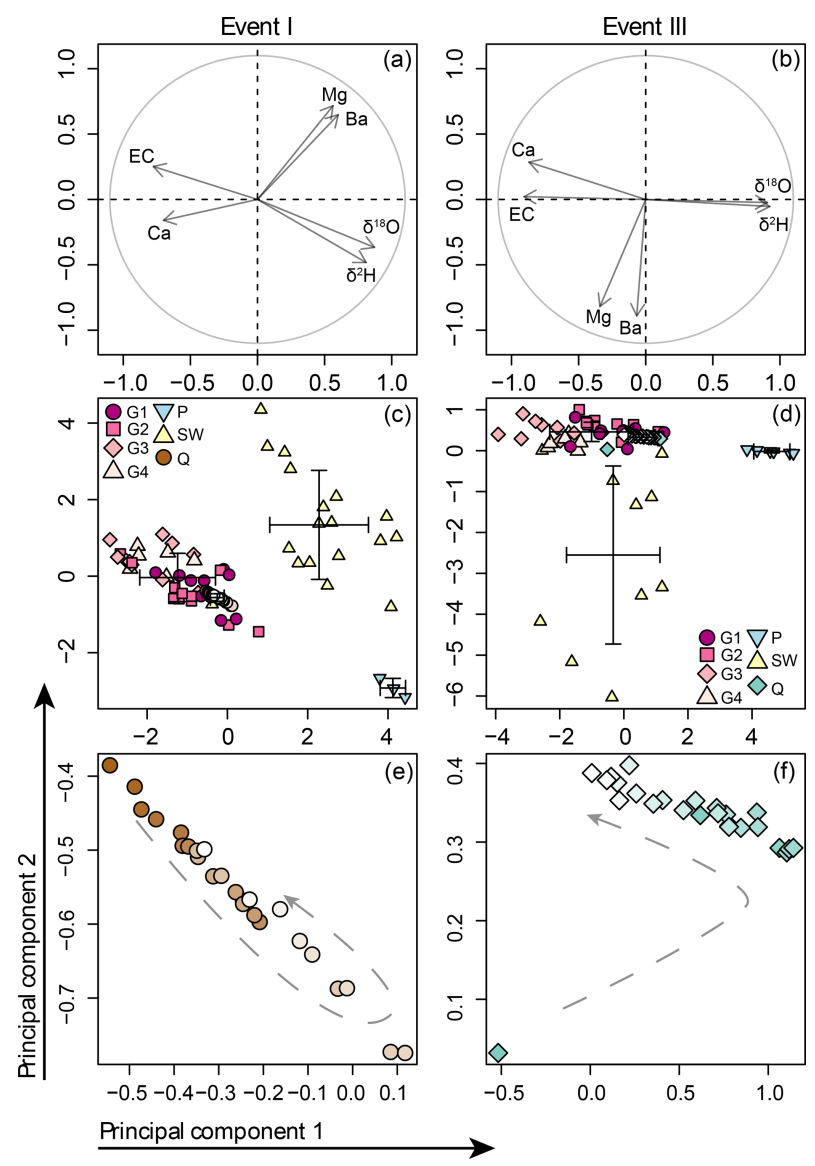

Figure 7. PCA results and mixing diagrams for events I (small event) and III (intermediate-sized event). In the biplots (a) and (b), the length of the arrow represents the explanatory power. The mixing diagrams based on the first two principal components (c and d) show the individual rainfall (light blue triangles), soil water (yellow triangles) and groundwater samples (purple circles, pink squares, light pink diamonds and rose triangles representing groundwater types 1-4; based on Kiewiet et al., 2019), and the streamflow ( $Q$ ) samples and average and standard deviation for each component (error bars). Panels (e) and (f) show an enlargement of the streamflow samples and highlight the evolution of the stream water composition (colours fade to white towards the end of the event); the general direction of change is indicated with a grey arrow and broken lines. The biplots and mixing plots for the events II and IV are shown in Fig. S4.

this comparison is often restricted because of insufficient spatial sampling (Penna and van Meerveld, 2019). Based on our experience for the Studibach, we see a clear need for further spatial sampling of groundwater and soil water in other catchments to determine this spatial variability.

\subsection{Which areas or sources contribute to stormflow?}

For the events included in this study, the estimated area that was hydrologically connected to the stream never fell to levels below a quarter of the catchment area, increased laterally
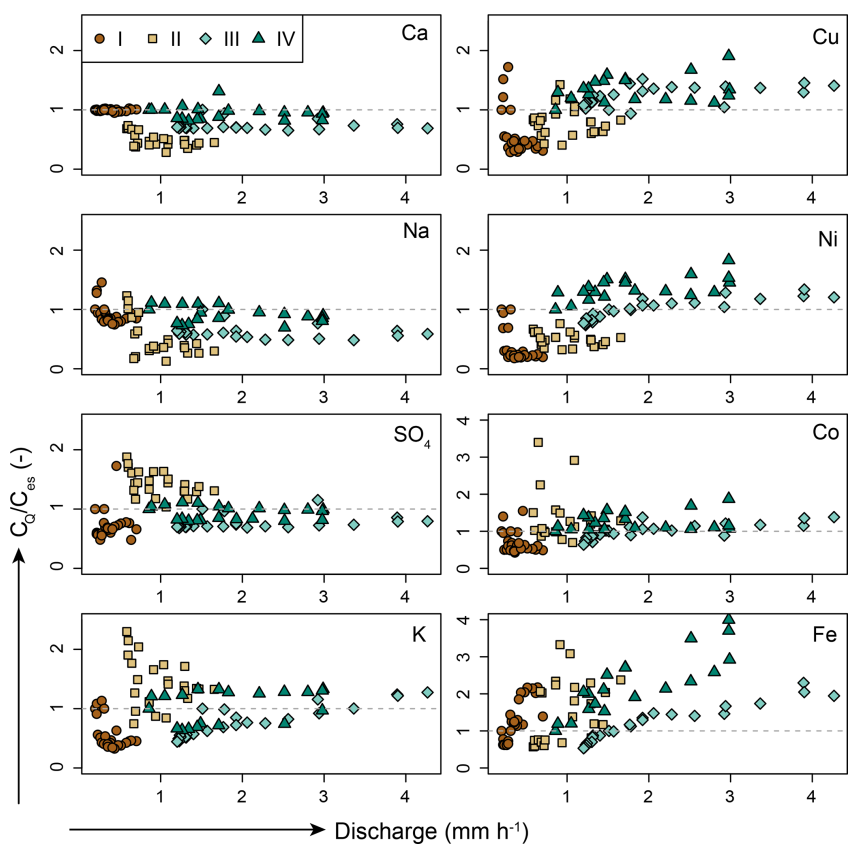

Figure 8. The ratio of the measured $\left(C_{Q}\right)$ and estimated stormflow concentrations ( $C_{\text {es }}$; Eq. 3 ) for calcium, sodium, sulfate, potassium, cobalt, copper, nickel and iron as a function of discharge at the catchment outlet. The broken grey line indicates where $C_{Q}$ and $C_{\mathrm{es}}$ are equal; the different symbols reflect the different events (I-IV). Note the difference in scale for cobalt and iron. For the relationship with the simulated fraction of the catchment that was connected to the stream, see Fig. S5.

upslope from the stream and increased to a maximum of twothirds of the catchment area. The simulated connected area during a relatively small event (event I; total rainfall $17 \mathrm{~mm}$ ) increased by a fifth of the catchment area, which implies that even small rainfall events can activate a sizable part of the catchment. The connectivity simulations for event II, however, suggest that during long-duration, low-intensity rainfall events, the change in connectivity can be small. For this event, the relative contributions of soil water and rainfall to stormflow were much higher than for the other events (Table 4).

Using a combination of different tracers to identify the sources of streamflow can be helpful because it enhances the likelihood that sources that contribute little to stormflow are identified (Barthold et al., 2017) and thereby reduces the risk of false conclusions about catchment functioning (Barthold et al., 2011). For instance, McCallum et al. (2012) used differential flow gauging and conservative (Cl) and non-conservative ( $\mathrm{Rn}$ and $\mathrm{EC}$ ) tracers to quantify the inflows and outflows of groundwater along three $\sim 30 \mathrm{~km}$ long stream reaches in the Cockburn River, Logan River and Nambucca River catchments $\left(>400 \mathrm{~km}^{2}\right)$ in southeastern Australia. They found that predictions made with flow data alone varied significantly from predictions that also included 
tracer data, and that the use of multiple tracers reduced the error in the calculation of the groundwater contributions. Moreover, the discrepancy between the results of source area analyses based on conservative and non-conservative tracers are hypothesised to indicate when sources other than baseflow and rainfall contribute to stream water (Kirchner, 2003). We found that the event water fractions from two-component hydrograph separation (isotopes) and EMMA (multi-tracer) were comparable (Table 4). Similar to our results, Ladouche et al. (2001) found for the $0.8 \mathrm{~km}^{2}$ Strengbach catchment in France that the hydrograph separation results based on $\delta^{18} \mathrm{O}$ $\left(f_{\mathrm{pe}}-10 \%\right)$ were relatively similar to the results of their mixing analyses (including $\mathrm{DOC}, \mathrm{Si}, \mathrm{Ba}$ and $\mathrm{U}$ ), and that a multi-tracer approach allowed them to distinguish between pre-event water contributions from the upper and lower part of the catchment. We found that concentrations of metals, such as iron or copper, were much higher than expected from mixing of rainfall and baseflow, whereas weathering-derived solutes, such as sodium or calcium, were lower than expected from mixing of rainfall and baseflow. We assume that the differences between measured and expected concentrations, particularly on the falling limb and at peak flow, are at least partly caused by contributions from groundwater sources or soil water (particularly for event II) that did not contribute to baseflow (see Table 3 for ratios of concentrations in different source waters). For instance, the differences for weatheringderived solutes could be due to contributions from soil water which has lower concentrations of these solutes than groundwater. The concentrations of iron increased throughout the event until peak flow and were higher on the falling limb than on the rising limb. Since riparian groundwater has relatively high concentrations of iron (Tables 2 and 3), contributions from riparian-like areas that did not contribute to baseflow (such as flatter areas away from the stream network) during rainfall events could explain this increase. Measured copper concentrations were much higher than expected for events III and IV but lower than expected for most samples of events I and II. Because copper concentrations are relatively high for hillslope groundwater and low in soil water (Table 2 and 3; Kiewiet et al., 2019), this could be an indication that the hillslopes did not actively contribute to streamflow during events I and II and were only activated after peak flow for events III and IV (see wide hysteresis for event I in Fig. 5, top row). However, the copper concentrations should then also not have increased compared to baseflow during event II, which was not the case (maximum $R_{\mathrm{Cu}}$ during event II -1.7 versus $1.0,1.0$ and 1.4 during event I, III and IV, respectively). The potassium concentrations were too variable to aid further interpretation, which is probably due to the high variation in potassium concentrations in soil water and groundwater (Table 2).

The contribution from soil water was considerable $\left(f_{\mathrm{SW}}\right.$ -0.27 ) for only one of the four events (event II; Table 4). This was a long, low-intensity event occurring on a relatively "dry" catchment (baseflow event I and II $-0.2 \mathrm{~mm} \mathrm{~h}^{-1}$ ver- sus $0.7 \mathrm{~mm} \mathrm{~h}^{-1}$ for event III and IV). Hagedorn et al. (2000), analysed three rainfall events $(7,8$ and $30 \mathrm{~mm})$ in the neighbouring Erlenbach catchment and showed a large contribution of soil water to streamflow. Their mixing diagrams using chloride and calcium indicate that the average contribution of the top soil to streamflow was larger than $50 \%$. However, chloride and calcium concentrations vary considerably in both soil and groundwater (average coefficient of variation -0.86 and 1.0 for eight soil water $(n=6$ to 18$)$ and 1.0 and 0.3 for nine groundwater ( $n=34$ to 47$)$ snapshot campaigns for chloride and calcium, respectively). Furthermore, the concentration of bivalent cations, like calcium, in rainwater can increase during transport through the canopy (Lindberg et al., 1986). Van Meerveld et al. (2018) showed that calcium concentrations in overland flow from small landslide areas in the Studibach were much higher than for other solutes, indicating rapid dissolution as well. The much lower soil water contributions found for this study compared to Hagedorn et al. (2000) may thus be partly caused by the choice of the tracers. Understanding the role of soil water for runoff generation is challenging because of the spatial variation in its amount (e.g. McMillan and Srinivasan, 2015), the horizontal and vertical spatial variation in soil water chemistry (Gottselig et al., 2016), and the importance of preferential flow (e.g. Wiekenkamp et al., 2016). Antecedent soil moisture conditions also affect runoff amounts and stream chemistry (Zehe et al., 2010; Uber et al., 2018; Knapp et al., 2020) as well as hillslope-stream connectivity (Penna et al., 2011). Further investigation of the response of soil water, the distribution of soil water chemistry and the interaction between soil water and groundwater during rainfall events is thus important if we want to understand the influence of soil water on hydrologic connectivity and when and where soil water contributes to streamflow.

The typically moderate event water fractions could indicate that overland flow is of minor importance for streamflow in the Studibach. However, overland flow does occur in the Studibach (van Meerveld et al., 2018). Saturation overland flow has been observed during sprinkling events for other sites on gleysols in Switzerland as well (Feyen et al., 1996; Weiler et al., 1999; Badoux et al., 2006). Given the low event water fractions, we suspect that the overland flow mixes with pre-event soil water on its way to the stream (Kienzler and Naef, 2008; Elsenbeer and Vertessy, 2000) or originates from exfiltrating soil water or groundwater and thus does not have the same composition as rainwater (Barthold et al., 2017). Alternatively, overland flow may infiltrate in unsaturated soils before reaching the stream and thus not influence the stream water composition.

\subsection{Hydrologic connectivity and stream water chemistry}

The simulations of the active and connected area suggest that the near-stream areas are most often connected and respond 
first to rainfall, highlighting their importance for the rapid generation of streamflow. The model results also showed that some areas remain disconnected from the stream (Fig. 4). Nippgen et al. (2015) found very similar connectivity patterns for a subcatchment of the Tenderfoot Creek Experimental Forest $\left(5.55 \mathrm{~km}^{2}\right)$ in central Montana, USA. They simulated the connected area over a 2 year period and found that it expanded from areas parallel to and close to the stream during low-flow conditions and to the hillslopes during highflow conditions, and that $10 \%$ of the catchment was never connected to the stream.

The change in stream water chemistry also suggests that the connected area increased rapidly because, even for small increases in discharge, stormflow could not be described as a mixture of rainfall and baseflow. However, there was no clear relationship between the extent of the hydrologically connected area and the discrepancy between the relative changes in the concentrations of conservative and non-conservative solutes (Fig. S5). Other studies that used stream water chemistry to investigate hydrological connectivity focused on one tracer that was clearly different for different source areas (e.g. Soulsby et al., 2007; Ocampo et al., 2006). These studies illustrated that for some catchments the changes in stream water chemistry reflect changes in hydrological connectivity. However, other studies showed that the interpretation of stream-based measurements may not always be straightforward because the changes in stream water chemistry can be obscured by dampening and mixing processes (Tetzlaff et al., 2014), or because a tracer might only reflect connectivity to a specific part of the catchment rather than catchment-wide connectivity (e.g. areas with high-DOC concentrations for Pacific et al., 2010). For instance, Pacific et al. (2010) compared changes in stream water DOC concentrations with estimates of upslope riparian-stream (URS) connectivity (methods cf. Jencso et al., 2009) in the Tenderfoot Creek catchment. They found a negative (though insignificant) relationship between stream DOC export and URS connectivity and showed that URS connectivity is particularly important for predicting DOC export when areas with high-DOC concentrations are connected to the stream. Multiple studies in the Girnock catchment in Scotland used stream water Gran alkalinity and isotopic composition to investigate hydrologic connectivity (Soulsby et al., 2007; Tetzlaff et al., 2014). Birkel et al. (2010), furthermore, explored the catchment's functioning with a spatially and temporally dynamic saturation model. These studies found that contributions from the upper soil layers and upslope areas dominated streamflow at higher flows, and that there was a soil moisture threshold for the contribution of these sources (Birkel et al., 2010). Furthermore, Tetzlaff et al. (2014) showed that the dynamic behaviour of the isotopic composition of stream water was in the range of the composition of soil water from the riparian peat soils at 10 and $30 \mathrm{~cm}$ deep and only deviated from this range during some larger events. They concluded from these results that precipitation inputs drive the dynamics of streamflow and stream water isotopic composition, but that the streamflow responses are dampened because the water travels through different hydropedological units.

Despite substantial changes in the hydrologically connected area and the large spatial variability in groundwater composition, we did not observe a distinct threshold in the relationship between the deviation of stream chemistry from conservative mixing of rainfall and baseflow and streamflow or the connected area. The gradual change in stream water chemistry might reflect the gradual increase in the connected area with increasing discharge for all of the studied events, except event I, for which the connectivity increased abruptly after peak discharge (top row in Fig. 5). Abbott et al. (2018) showed that changes in stream water composition with increasing discharge and connectivity are less pronounced for catchments with a myriad of source areas than for catchments with fewer different landscape elements. The Studibach is characterised by many small landscape elements, particularly steep hillslopes and flatter wet areas, which formed due to landslides and soil creep and which induce small-scale differences in drainage and thus soil and vegetation development. Hence, activation of different landscape elements might occur gradually and at many different places across the catchment (i.e. the connected area extends from flat locations to the hillslopes at many different locations), but these elements all have a slightly different chemical composition. From this perspective, it is perhaps not surprising that solute concentrations in stormflow changed little compared to the spatial variability in the end-member composition because streamflow is a mixture of the many different water sources in a catchment.

Alternatively, the simulations of the active and connected areas might overestimate the change in the source areas compared to reality. Although most flow occurs in the upper, more permeable layer of the soil, seepage to deeper soil layers (Feyen et al., 1999), or to the bedrock in areas where there is no continuous groundwater table in the Gleysol, may have limited the downslope travel distance (cf. Jackson et al., 2014). We did not consider a limitation of the downslope travel distance due to bedrock infiltration because the occurrence of a permanent water table in a large part of the catchment implies that percolation to the bedrock is very slow. However, bedrock infiltration might occur at some locations (e.g. the more densely rooted forested sections on steeper, better-drained soils) and might decrease the lateral distance that a water parcel can travel. Additionally, we did not consider an offset in the timing of the simulated connectivity and response in stream water chemistry due to the travel time to the stream or mixing of hillslope and riparian groundwater in the riparian zone. Chanat and Hornberger (2003) showed with a virtual experiment for a $10 \mathrm{~km}^{2}$ hypothetical catchment that the change in the chemical signature of the stream water can be delayed relative to the change in discharge, and that this delay was larger when the near-stream reservoir (i.e. riparian zone) was larger. Their findings are thus especially 
important to consider for "wet" catchments that have a large near-stream reservoir or for which the near-stream reservoir expands quickly. Furthermore, the stormflow composition is the result of mixing of contributions from different source areas. Subsurface mixing can result in temporally variable endmember compositions. Frameworks to handle time-variable end-member compositions exist (Harris et al., 1995), but there are obvious challenges, such as measuring these timevariable compositions. Furthermore, mixing of different water sources will dampen the tracer signal (Abbott et al., 2018; Tetzlaff et al., 2014) or may even chemically "reset" the hillslope signal as it mixes with riparian groundwater (Tetzlaff et al., 2014; Lidman et al., 2017).

\section{Conclusions}

The results of this study show that the spatial variability in soil water and groundwater compositions across the small, pre-Alpine headwater study catchment was large. Hydrograph separation and EMMA indicated that pre-event groundwater was the dominant source of streamflow, and that soil water contributions were minimal for three of the four events. For most solutes, the stream water concentrations could not be explained by conservative mixing of baseflow and rainfall. The differences were largest at high discharges. This suggests that this deviation may indicate the contribution from new contributing sources due to the expansion of the connected area. Concentrations of weatheringderived solutes decreased more than expected, which might be due to the contributions of soil water. In contrast, concentrations of iron and copper increased more than expected, which might be due to contributions from riparian-like areas and hillslopes, respectively. Thus, the differences between the expected and measured concentrations could be partly explained by contributions from other source areas. However, there was no threshold in the relationship between streamflow and the deviations of the measured concentrations and expected concentrations based on conservative mixing, suggesting that there was no sudden activation and connection of source areas. The lack of a threshold relationship between the deviations in the solute concentrations and streamflow made it more difficult to infer changes in hydrological connectivity from the stream water solute concentrations. Overall, this work shows that inferring hydrological connectivity from solute concentrations is not straightforward, especially if we consider the large variability of the tracer concentrations in the different water sources. The gradual changes in stream water chemistry during events are likely the result of increases in the contributions from many (small) landscape elements in the catchment and reflect the gradual increase in hydrologic connectivity.
Data availability. The data that support the findings of this study are available from the corresponding author upon reasonable request.

Supplement. The supplement related to this article is available online at: https://doi.org/10.5194/hess-24-3381-2020-supplement.

Author contributions. LK and IvM conceptualised the study. LK collected and analysed the data and prepared the first draft of the manuscript. IvM, JS and MS provided recommendations for the data analysis, participated in discussions about the results, and edited and commented on the manuscript.

Competing interests. The authors declare that they have no conflict of interest.

Acknowledgements. This work would not have been possible without the help and support of many people in the field and lab. We particularly thank Michael Rinderer and Benjamin Fischer for the initial installation of the wells, weirs and flumes; Michael Rinderer for running the data-based connectivity model for the Studibach catchment; Barbara Herbstritt for the isotope analyses; and Bjorn Studer for the cation and anion analyses. We thank the editor and two anonymous reviewers for their helpful comments to improve the paper, and the Oberallmeindkorporation Schwyz (OAK), the municipality of Alpthal and the Department of Environment of the Canton of Schwyz for the excellent co-operation.

Review statement. This paper was edited by Pilar Llorens and reviewed by two anonymous referees.

\section{References}

Abbott, B. W., Gruau, G., Zarnetske, J. P., Moatar, F., Barbe, L., Thomas, Z., Fovet, O., Kolbe, T., Gu, S., Pierson-Wickmann, A. C., Davy, P., and Pinay, G.: Unexpected spatial stability of water chemistry in headwater stream networks, Ecol. Lett., 21, 296308, https://doi.org/10.1111/ele.12897, 2018.

Allaire, S. E., Sylvain, C., Lange, S. F., Thériault, G., and Lafrance, P.: Potential Efficiency of Riparian Vegetated Buffer Strips in Intercepting Soluble Compounds in the Presence of Subsurface Preferential Flows, PloS one, 10, 1-21, https://doi.org/10.1371/journal.pone.0131840, 2015.

Badoux, A., Witzig J., Germann P. F., Kienholz H., Lüscher P., Weingartner R., and Hegg C.: Investigations on the runoff generation at the profile and plot scales, Swiss Emmental, Hydrol. Process., 20, 377-394, https://doi.org/10.1002/hyp.6056, 2006.

Barthold, F. K., Tyralla, C., Schneider, K., Vaché, K. B., Frede, H. G., and Breuer, L.: How many tracers do we need for end member mixing analysis (EMMA)? A sensitivity analysis, Water Resour. Res., 47, 1-14, https://doi.org/10.1029/2011WR010604, 2011. 
Barthold, F. K., Turner, B. L., Elsenbeer, H., and Zimmermann, A.: A hydrochemical approach to quantify the role of return flow in a surface flow-dominated catchment, Hydrol. Process., 31, 10181033, https://doi.org/10.1002/hyp.11083, 2017.

Beven, K. J. and Kirkby, M. J.: A physically based, variable contributing area model of basin hydrology, Hydrolog. Sci. J., 24, 43-69, https://doi.org/10.1080/02626667909491834, 1979.

Birkel, C., Tetzlaff, D., Dunn, S. M., and Soulsby, C.: Towards a simple dynamic process conceptualization in rainfallrunoff models using multi-criteria calibration and tracers in temperate, upland catchments, Hydrol. Process., 24, 260-275, https://doi.org/10.1002/hyp.7478, 2010.

Blume, T. and van Meerveld, H. J. I.: From hillslope to stream: methods to investigate subsurface connectivity, WIREs Water, 2, 177-198 https://doi.org/10.1002/wat2.1071, 2015.

Bracken, L. J. and Croke, J.: The concept of hydrological connectivity and its contribution to understanding runoffdominated geomorphic systems, Hydrol. Process., 21, 22672274, https://doi.org/10.1002/hyp.6313, 2007.

Brown, V. A., McDonnell, J. J., Burns, D. A., and Kendall, C.: The role of event water, a rapid shallow flow component, and catchment size in summer stormflow, J. Hydrol., 217, 171-190, https://doi.org/10.1016/S0022-1694(98)00247-9, 1999.

Burns, D. A., Hooper, R. P., McDonnell, J. J., Freer, J. E., Kendall, C., and Beven, K.: Base cation concentrations in subsurface flow from a forested hillslope: The role of flushing frequency, Water Resour. Res. 34, 3535-3544, https://doi.org/10.1029/98WR02450, 1998.

Buttle, J. M.: Isotope hydrograph separations and rapid delivery of pre-event water from drainage basins, Prog. Phys. Geogr. 18, 1641, https://doi.org/10.1177/030913339401800102, 1994.

Chanat, J. G. and Hornberger, G. M.: Modeling catchment-scale mixing in the near-stream zone - Implications for chemical and isotopic hydrograph separation, Geophys. Res. Lett., 30, 1091, https://doi.org/10.1029/2002GL016265, 2003.

Christophersen, N. and Hooper, R. P.: Multivariate Analysis of Stream Water Chemical Data' The Use of Principal Components Analysis for the End-Member Mixing Problem, Water Resour. Res., 28, 99-107, https://doi.org/10.1029/91WR02518, 1992.

Detty, J. M. and McGuire, K. J.: Threshold changes in storm runoff generation at a till - mantled headwater catchment, Water. Resour. Res., 46, 1-15, https://doi.org/10.1029/2009WR008102, 2010.

Devito, K. J. and Hill, A. R.: Sulphate dynamics in relation to groundwater - Surface water interactions in headwater wetlands of the southern Canadian Shield, Hydrol. Process., 11, 485-500, https://doi.org/10.1002/(SICI)10991085(199704)11:5<485::AID-HYP455>3.0.CO;2-F, 1997.

Elsenbeer, H. and Vertessy, R. A.: Stormflow generation and flowpath characteristics in an Amazonian rainforest catchment, Hydrol. Process., 14, 2367-2381, https://doi.org/10.1002/10991085(20001015)14:14<2367::AID-HYP107>3.0.CO;2-H, 2000.

Evans, C. and Davies, T. D.: Causes of concentration/discharge hysteresis and its potential as a tool for analysis of episode hydrochemistry, Water Resour. Res., 34, 129-137, https://doi.org/10.1029/97WR01881, 1998.

Feyen, H., Leuenberger, J., Papritz, A., Gysi, M., Flühler, H., and Schleppi P.: Runoff processes in catchments with a small scale topography, Phys. Chem. Earth., 21, 177-181, https://doi.org/10.1016/S0079-1946(97)85581-4, 1996.

Feyen, H., Wunderli, H., Wydler, H., and Papritz, A.: A tracer experiment to study flow paths of water in a forest soil, J. Hydrol., 225, 155-167, https://doi.org/10.1016/S0022-1694(99)00159-6, 1999.

Fischer, B. M. C., Rinderer, M., Schneider, P., Ewen, T., and Seibert, J.: Contributing sources to baseflow in pre-alpine headwaters using spatial snapshot sampling, Hydrol. Process., 29, 5321-5336, https://doi.org/10.1002/hyp.10529, 2015.

Fischer, B. M. C., Stähli, M., and Seibert, J.: Pre-event water contributions to runoff events of different magnitude in pre-alpine headwaters, Hydrol. Res., 48, 28-47, https://doi.org/10.2166/nh.2016.176, 2017.

Fischer, B. M. C., Aemisegger, F., Graf, P., Sodemann, H., and Seibert, J.: Assessing the Sampling Quality of a Low-Tech Low-Budget Volume-Based Rainfall Sampler for Stable Isotope Analysis, Front. Earth Sci., 7, 1-8, https://doi.org/10.3389/feart.2019.00244, 2019.

Genereux, D.: Quantifying uncertainty in tracer-based hydrograph separations, Water Resour. Res., 34, 915-919, https://doi.org/10.1029/98WR00010, 1998.

Godsey, S. E., Kirchner, J. W., and Clow, D. W.: Concentration - discharge relationships reflect chemostatic characteristics of US catchments, Hydrol. Process., 23, 1844-1864, https://doi.org/10.1002/hyp.7315, 2009.

Gottselig, N., Wiekenkamp, I., Weihermüller, L., Brüggemann, N., Berns, A. E., Bogena, H. R., Borchard, N., Klumpp, E., Lücke, A., Missong, A., Pütz, T., Vereecken, H., Huisman, J. A., and Bol, R.: A Three-Dimensional View on Soil Biogeochemistry: A Dataset for a Forested Headwater Catchment, J. Environ. Qual., 46, 210-218, https://doi.org/10.2134/jeq2016.07.0276, 2016.

Hagedorn, F., Schleppi, P., Waldner, P., and Flühler, H.: Export of dissolved organic carbon and nitrogen from Gleysol dominated catchments-the significance of water flow paths, Biogeochem., 50, 137-161, https://doi.org/10.1023/A:1006398105953, 2000.

Harris, D. M., McDonnell, J. J., and Rodhe, A.: Hydrograph Separation Using Continuous Open System Isotope Mixing, Water Resour. Res., 31, 157-171, https://doi.org/10.1029/94WR01966, 1995.

Hooper, R. P.: Applying the scientific method to small catchment studies: a review of the Panola Mountain experience, Hydrol Process., 15, 2039-2050, https://doi.org/10.1002/hyp.255, 2001.

Hooper, R. P. and Shoemaker, C. A.: A Comparison of Chemical and Isotopic Hydrograph Separation, Water Resour. Res., 22, 1444-1454, https://doi.org/10.1029/WR022i010p01444, 1986.

Hooper, R. P., Christophersen, N., and Peters, N. E.: Modelling streamwater chemistry as a mixture of soilwater end-members - An application to the Panola Mountain catchment, Georgia, U.S.A., J. Hydrol., 116, 321-343, https://doi.org/10.1016/00221694(90)90131-G, 1990.

Hopp, L. and McDonnell, J. J.: Connectivity at the hillslope scale: Identifying interactions between storm size, bedrock permeability, slope angle and soil depth, J. Hydrol., 376, 378-391, https://doi.org/10.1016/j.jhydrol.2009.07.047, 2009.

Hornberger, G. M., Scanlon, T. M., and Raffensperger, J. P.: Modelling transport of dissolved silica in a forested headwater catchment: the effect of hydrological and chemical time scales on hys- 
teresis in the concentration - discharge relationship, Hydrol. Process., 15, 2029-2038, https://doi.org/10.1002/hyp.254, 2001.

Jackson, C. R., Bitew, M., and Du, E.: When interflow also percolates: downslope travel distances and hillslope process zones, Hydrol. Process., 28, 3195-3200, https://doi.org/10.1002/hyp.10158, 2014.

James, A. L. and Roulet, N. T.: Investigating the applicability of end-member mixing analysis (EMMA) across scale: A study of eight small, nested catchments in a temperate forested watershed, Water Resour. Res., 42, W08434, https://doi.org/10.1029/2005WR004419, 2006.

Jencso, K. G. and McGlynn, B. L.: Hierarchical controls on runoff generation: Topographically driven hydrologic connectivity, geology, and vegetation, Water Resour. Res., 47, 1-16, https://doi.org/10.1029/2011WR010666, 2011.

Jencso, K. G., McGlynn, B. L., Gooseff, M. N., Wondzell, S. M., Bencala, K. E., and Marshall, L. A.: Hydrologic connectivity between landscapes and streams: transferring reach and plot scale understanding to the catchment scale, Water Resour. Res., 45, W04428, https://doi.org/10.1029/2008WR007225, 2009.

Kaushal, S. S. Gold, A. J., Bernal, S., Newcomer Johnson, T. A., Addy, K., Burgin, A., Burns, D. A., Coble, A. A., Hood, E., Lu, Y., Mayer, P., Minor, E. C., Schroth, A. W., Vidon, P., Wilson, H., Xenopoulos, M. A., Doody, T., Galella, J. G., Goodling, P., Haviland, K., Haq, S., Wessel, B., Wood, K. L., Jaworski, N., and Belt, K. T.: Watershed "chemical cocktails": forming novel elemental combinations in Anthropocene fresh waters, Biogeochem., 141, 281-305, https://doi.org/10.1007/s10533-018-0502-6, 2018.

Kennedy, V. C., Zellweger, G. W., and Avanzino, R. J.: Variation of rain chemistry during storms at two sites in northern California, Water Resour. Res., 15, 687-702, https://doi.org/10.1029/WR015i003p00687, 1979.

Kienzler, P. M. and Naef, F.: Temporal variability of subsurface stormflow formation, Hydrol. Earth Syst. Sci., 12, 257-265, https://doi.org/10.5194/hess-12-257-2008, 2008.

Kiewiet, L., von Freyberg, J., and van Meerveld, H. J. I.: Spatiotemporal variability in hydrochemistry of shallow groundwater in a small pre-alpine catchment: The importance of landscape elements, Hydrol. Process., 33, 2502-2522, https://doi.org/10.1002/hyp.13517, 2019.

Kiewiet, L., van Meerveld, I., and Seibert, J.: Effects of spatial variability in the groundwater isotopic composition on hydrograph separation results for a pre-alpine catchment, Water Resour. Res., 56, e2019WR026855, https://doi.org/10.1029/2019WR026855, 2020.

Kirchner, J. W.: A double paradox in catchment hydrology and geochemistry, Hydrol Process., 17, 871-874 https://doi.org/10.1002/hyp.5108, 2003.

Knapp, J. L. A., von Freyberg, J., Studer, B., Kiewiet, L., and Kirchner, J. W.: Concentration-discharge relationships vary among hydrological events, reflecting differences in event characteristics, Hydrol. Earth Syst. Sci., 24, 2561-2576, https://doi.org/10.5194/hess-24-2561-2020, 2020.

Ladouche, B., Probst, A., Viville, D., Idir, S., Baqué, D., Loubet, M., Probst, J. L., and Bariac, T.: Hydrograph separation using isotopic, chemical and hydrological approaches (Strengbach catchment, France), J. Hydrol., 242, 255-274, https://doi.org/10.1016/S0022-1694(00)00391-7, 2001.
Landwehr, J. M. and Coplen, T. B.: Line-conditioned excess: A new method for characterizing stable hydrogen and oxygen isotope ratios in hydrologic systems (IAEA-CSP-26/P), International Atomic Energy Agency (IAEA), available at: https://inis. iaea.org/search/search.aspx?orig_q=RN:37043527 (last access: June 2020), 2006.

Lehmann, P., Hinz, C., McGrath, G., Tromp-van Meerveld, H. J., and McDonnell, J. J.: Rainfall threshold for hillslope outflow: an emergent property of flow pathway connectivity, Hydrol. Earth Syst. Sci., 11, 1047-1063, https://doi.org/10.5194/hess-11-10472007, 2007.

Lidman, F., Boily, Å., Laudon, H., and Köhler, S. J.: From soil water to surface water - how the riparian zone controls element transport from a boreal forest to a stream, Biogeosciences, 14, 30013014, https://doi.org/10.5194/bg-14-3001-2017, 2017.

Lindberg S. E., Lovett G. M., Richter D. D., and Johnson D. W., Atmospheric Deposition and Canopy Interactions of Major Ions in a Forest, Science, 231, 141-145, https://doi.org/10.1126/science.231.4734.141, 1986.

McCallum, J. L., Cook, P. G., Brunner, P., Berhane, D., Rumpf, C., and McMahon, G. A., Quantifying groundwater flows to streams using differential flow gaugings and water chemistry, J. Hydrol., 416-417, 118-132, https://doi.org/10.1016/j.jhydrol.2011.11.040, 2012.

McGlynn, B. L. and McDonnell, J. J.: Quantifying the relative contributions of riparian and hillslope zones to catchment runoff, Water Resour. Res., 39, 1310, https://doi.org/10.1029/2003WR002091, 2003.

McMillan, H. K. and Srinivasan, M. S.: Characteristics and controls of variability in soil moisture and groundwater in a headwater catchment, Hydrol. Earth Syst. Sci., 19, 1767-1786, https://doi.org/10.5194/hess-19-1767-2015, 2015.

Nippgen, F., McGlynn, B. L., and Emanuel, R. E.: The spatial and temporal evolution of contributing areas, Water Resour. Res., 51, 4550-4573, https://doi.org/10.1002/2014WR016719, 2015.

Ocampo, C. J., Sivapalan, M., and Oldham, C.: Hydrological connectivity of upland-riparian zones in agricultural catchments: Implications for runoff generation and nitrate transport, J. Hydrol., 331, 643-658, https://doi.org/10.1016/j.jhydrol.2006.06.010, 2006.

Oswald, C. J., Richardson, M. C., and Branfireun, B. A.: Water storage dynamics and runoff response of a boreal Shield headwater catchment, Hydrol. Process., 25, 3042-3060, https://doi.org/10.1002/hyp.8036, 2011.

Pacific, V. J., Jensco, K. G., and McGlynn, B. L.: Variable flushing mechanisms and landscape structure control stream DOC export during snowmelt in a set of nested catchments, Biogeochem., 99, 193-211, https://doi.org/10.1007/s10533-009-9401-1, 2010.

Penna, D. and van Meerveld, H. J.: Spatial variability in the isotopic composition of water in small catchments and its effect on hydrograph separation, WIREs Water, 2019, e1367, https://doi.org/10.1002/wat2.1367, 2019.

Penna, D., Tromp-van Meerveld, H. J., Gobbi, A., Borga, M., and Dalla Fontana, G.: The influence of soil moisture on threshold runoff generation processes in an alpine headwater catchment, Hydrol. Earth Syst. Sci., 15, 689-702, https://doi.org/10.5194/hess-15-689-2011, 2011. 
R Core Team: A language and environment for computing. R Foundation for Statistical Computing, Vienna, Austria, available at: http://www.r-project.org/ (last access: 5 May 2020), 2013.

Rinderer, M., van Meerveld, H. J., and Seibert, J.: Topographic controls on shallow groundwater levels in a steep, prealpine catchment, Water Resour. Res., 50, 6067-6080, https://doi.org/10.1002/2013WR015009, 2014.

Rinderer, M., van Meerveld, I., Stähli, M., and Seibert, J.: Is groundwater response timing in a pre-alpine catchment controlled more by topography or by rainfall?, Hydrol. Process., 30, 1036-1051, https://doi.org/10.1002/hyp.10634, 2015.

Rinderer, M., van Meerveld, H. J. I., and McGlynn, B.: From Points to Patterns: Using Groundwater Time Series Clustering to Investigate Subsurface Hydrological Connectivity and Runoff Source Area Dynamics, Water Resour. Res. 55, 1-23, https://doi.org/10.1029/2018WR023886, 2019.

Schneider, P., Pool, S., Strouhal, L., and Seibert, J.: True colors experimental identification of hydrological processes at a hillslope prone to slide, Hydrol. Earth Syst. Sci., 18, 875-892, https://doi.org/10.5194/hess-18-875-2014, 2014.

Seibert, J., Grabs, T., Köhler, S., Laudon, H., Winterdahl, M., and Bishop, K.: Linking soil- and stream-water chemistry based on a Riparian Flow-Concentration Integration Model, Hydrol. Earth Syst. Sci., 13, 2287-2297, https://doi.org/10.5194/hess-13-22872009, 2009.

Soulsby, C., Tetzlaff, D., van den Bedem, N., Malcolm, I. A., Bacon, P. J., and Youngson, A. F.: Inferring groundwater influences on surface water in montane catchments from hydrochemical surveys of springs and streamwaters, J. Hydrol., 333, 199-213, https://doi.org/10.1016/j.jhydrol.2006.08.016, 2007.

Stähli, M.: Longterm hydrological observatory Alptal (central Switzerland), available at: https://www.envidat.ch/dataset/ longterm-hydrological-observatory-alptal-central-switzerland (last access: 16 August 2019), 2018.

Stähli, M. and Gustafsson, D.: Long-term investigations of the snow cover in a subalpine semi-forested catchment, Hydrol. Process., 20, 411-428, https://doi.org/10.1002/hyp.6058, 2006.

Stieglitz, M., Shaman, J., McNamara, J., Engel, V., Shanley, J., and Kling, G. W.: An approach to understanding hydrologic connectivity on the hillslope and the implications for nutrient transport, Global Biogeochem. Cy., 17, 1105, https://doi.org/10.1029/2003GB002041, 2003.

Tetzlaff, D., Birkel, C., Dick, J., Geris, J., and Soulsby, C.: Storage dynamics in hydropedological units control hillslope connectivity, runoff generation, and the evolution of catchment transit time distributions, Water Resour. Res., 50, 969-985, https://doi.org/10.1002/2013WR014147, 2014.
Uber, M., Vandervaere, J.-P., Zin, I., Braud, I., Heistermann, M., Legoût, C., Molinié, G., and Nord, G.: How does initial soil moisture influence the hydrological response? A case study from southern France, Hydrol. Earth Syst. Sci., 22, 6127-6146, https://doi.org/10.5194/hess-22-6127-2018, 2018.

Uhlenbrook, S., Roser, S., and Tilch, N.: Hydrological process representation at the meso-scale: the potential of a distributed, conceptual catchment model, J. Hydrol., 291, 278-296, https://doi.org/10.1016/j.jhydrol.2003.12.038, 2004.

von Freyberg, J., Studer, B., Rinderer, M., and Kirchner, J. W.: Studying catchment storm response using event- and pre-event-water volumes as fractions of precipitation rather than discharge, Hydrol. Earth Syst. Sci., 22, 5847-5865, https://doi.org/10.5194/hess-22-5847-2018, 2018.

van Meerveld, H. J., Seibert, J., and Peters, N. E.: Hillsloperiparian-stream connectivity and flow directions at the Panola Mountain Research Watershed, Hydrol. Process., 29, 35563574, https://doi.org/10.1002/hyp.10508, 2015.

van Meerveld, H. J. I., Fischer, B. M. C., Rinderer, M., Stähli, M., and Seibert, J.: Runoff generation in a pre-alpine catchment: A discussion between a tracer and a shallow groundwater hydrologist, Cuad. Investig. Geogr., 44, 429-452, https://doi.org/10.18172/cig.3349, 2018.

Weiler, M., Scherrer, S., Naef, F., and Burlando, P.: Hydrograph separation of runoff components based on measuring hydraulic state variables, tracer experiments and weighting methods, IAHS Publications, 258, 249-255, 1999.

Wiekenkamp, I., Huisman, J. A., Bogena, H. R., Lin, H. S., and Vereecken, H.: Spatial and temporal occurrence of preferential flow in a forested headwater catchment, J. Hydrol., 534, 139149, https://doi.org/10.1016/j.jhydrol.2015.12.050, 2016.

Zehe, E., Graeff, T., Morgner, M., Bauer, A., and Bronstert, A.: Plot and field scale soil moisture dynamics and subsurface wetness control on runoff generation in a headwater in the Ore Mountains, Hydrol. Earth Syst. Sci., 14, 873-889, https://doi.org/10.5194/hess-14-873-2010, 2010.

Zuecco, G., Penna, D., Borga, M., and van Meerveld, H. J.: A versatile index to characterize hysteresis between hydrological variables at the runoff event timescale, Hydrol. Process., 30, 14491466, https://doi.org/10.1002/hyp.10681, 2016.

Zuecco, G., Rinderer, M., Penna, D., Borga, M., and van Meerveld, H. J.: Quantification of subsurface hydrologic connectivity in four headwater catchments using graph theory, Sci. Total Environ., 646, 1265-1280, https://doi.org/10.1016/j.scitotenv.2018.07.269, 2019. 